\title{
Bearing Burdens: Religious Accommodations That Adversely Affect Coworker Morale
}

\begin{abstract}
DALLAN F. FLAKE*
This Article addresses the conflict that arises when accommodating an employee's religious beliefs threatens coworker morale. Research overwhelmingly shows morale is critical to both individual and organizational performance. Because perceptions of equity and fairness greatly influence morale, an accommodation that affords an employee preferential treatment can cause resentment, jealousy, and anger among coworkers-particularly if the accommodation negatively impacts the working conditions of other employees. Despite the unequivocal importance of coworker morale, some courts are hesitant to acknowledge it as a legitimate basis for denying a religious accommodation. Consequently, the case law is inconsistent and confusing. To ensure courts give coworker morale the protection it warrants, I argue courts should: (1) distinguish between valid and invalid reasons why an accommodation threatens morale; (2) accept harm to employee morale as a sufficient basis to deny an accommodation without requiring further proof of how lowered morale hurts an employer's business; and (3) allow an employer to establish undue hardship based on the reasonable likelihood an accommodation would harm morale. These changes could help strike an appropriate balance between an employee's freedom of religious expression, an employer's right to maintain a high-morale workplace, and coworkers' expectations of performing their jobs without undue interference.
\end{abstract}

\section{TABLE OF CONTENTS}

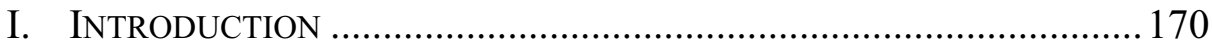

II. WHY MORALE MATTERS ............................................................ 173

A. How Morale Impacts Performance...................................... 174

B. How Religious Accommodations Affect Morale .................. 178

III. COWORKER RightS UNDER TITLE VII ...................................... 180

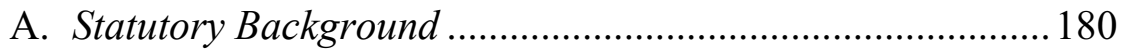

B. Supreme Court Analysis of Coworker Rights .................... 182

C. EEOC Interpretation of Coworker Rights ......................... 187

IV. JUDICIAL ANALYSIS OF MORALE-BASED HARDSHIPS .................... 190

A. Employer's Reasonable Belief ............................................ 190

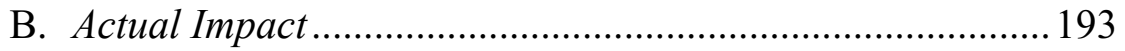

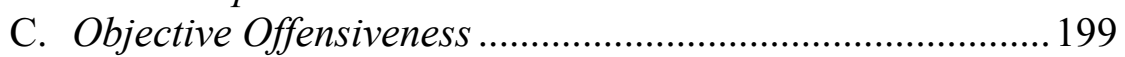

D. Harm to the Employer....................................................201

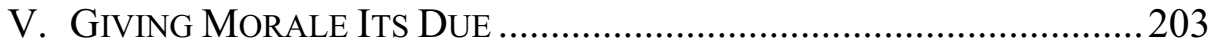

A. Distinguishing Valid from Invalid Harm to Morale ............ 204

${ }^{*}$ Visiting Assistant Professor of Sociology, Brigham Young University, Provo, Utah; J.D., University of Michigan Law School; B.S. and M.S., Brigham Young University. 
1. Harm to Morale Based on Religious Animus .................204

2. Harm to Morale Based on Coworkers' Perceptions of Unfairness .................................................................2205

3. Harm to Morale Based on an Accommodation's Impact on Other Workers' Employment .........................2207

B. Proving Undue Hardship Through Harm to Morale Alone..... 208

C. Proving Undue Hardship Based on Reasonable Likelihood of Harm. 210

D. Potential Impact

VI. CONCLUSION 215

\section{INTRODUCTION}

A Walmart pharmacist refuses to fill birth control prescriptions because of his church's stance against contraception. ${ }^{1}$ A Waffle House manager objects to working Saturdays because he believes it is a sin to perform labor on his Sabbath. ${ }^{2}$ A Chevron machinist refuses to shave his religiously prescribed beard in violation of company safety policies. ${ }^{3}$ A Hewlett-Packard customer support representative posts biblical passages condemning homosexuality above his cubicle. ${ }^{4}$ A Consolidated Freightways trucker seeks an exemption from overnight routes with female partners to avoid the appearance of evil. ${ }^{5}$ JBS meatpackers demand unscheduled breaks to complete their five daily prayers. ${ }^{6}$

Under Title VII of the Civil Rights Act of 1964, an employer must accommodate religious beliefs such as these unless doing so would cause "undue hardship on the conduct of the employer's business." This is not a particularly onerous burden: the Supreme Court has held an employer can establish undue hardship if an accommodation would result in "more than a de minimis cost." 8 Employers often prove undue hardship simply by showing an accommodation would cost money, ${ }^{9}$ hurt productivity, ${ }^{10}$ compromise safety, ${ }^{11}$

\footnotetext{
${ }^{1}$ See Noesen v. Med. Staffing Network, Inc., 232 F. App'x 581, 583 (7th Cir. 2007).

2 See Vaughn v. Waffle House, Inc., 263 F. Supp. 2d 1075, 1077 (N.D. Tex. 2003).

${ }^{3}$ See Bhatia v. Chevron U.S.A., Inc., 734 F.2d 1382, 1383 (9th Cir. 1984).

${ }^{4}$ See Peterson v. Hewlett-Packard Co., 358 F.3d 599, 601 (9th Cir. 2004).

5 See Virts v. Consol. Freightways Corp. of Del., 285 F.3d 508, 512 (6th Cir. 2002).

${ }^{6}$ See EEOC v. JBS USA, LLC, No. 8:10CV318, 2013 WL 6621026, at*17 (D. Neb.

742 U.S.C. $\$ 2000 \mathrm{e}(\mathrm{j})(2012)$.

${ }^{8}$ Trans World Airlines, Inc. v. Hardison, 432 U.S. 63, 84 (1977).

${ }^{9}$ E.g., El-Amin v. First Transit Inc., No. 1:04-CV-72, 2005 WL 1118175, at *6 (S.D. Ohio May 11, 2005) (undue hardship where accommodating plaintiff's beard would cost employer $\$ 25$ per day under terms of customer contract).
} Oct. 11, 2013). 
or conflict with corporate image. ${ }^{12}$ But what if the cost of accommodation falls primarily on other employees rather than the business itself? Because accommodations rarely take place in isolation, preferential treatment of one employee almost always necessitates less favorable treatment of coworkers. ${ }^{13}$ For instance, exempting a pharmacist from handling birth control would require coworkers to fill a greater share of prescriptions, granting a manager Saturdays off would mean someone not otherwise scheduled to work must fill in, allowing a machinist to wear a beard could force other crewmembers to assume a disproportionate share of potentially hazardous work, permitting a customer service representative to post scriptural passages could offend others, excusing a trucker from routes with female partners could force a driver with more seniority to take a route he otherwise might not choose, and authorizing meatpackers to take prayer breaks might force other employees to work harder and faster in their absence. In each of these examples, there is a real threat the accommodation will negatively impact other workers' employment and consequently lower morale. Is this a legitimate reason to deny an accommodation, or should other employees' feelings about an accommodation be irrelevant to an employer's obligations under Title VII?

${ }^{10}$ E.g., Wilson v. U.S. W. Commc'ns, 58 F.3d 1337, 1342 n.3 (8th Cir. 1995) (undue hardship where allowing plaintiff to wear a button depicting a fetus decreased coworker productivity by forty percent).

${ }^{11}$ E.g., Finnie v. Lee Cnty., 907 F. Supp. 2d 750, 776-84 (N.D. Miss. 2012) (allowing Pentecostal juvenile detention officer to wear a skirt instead of pants posed safety and security concerns that amounted to undue hardship); EEOC v. GEO Grp., Inc., 616 F.3d 265, 274-77 (3d Cir. 2010) (allowing Muslim prison guard to wear headscarf constituted undue hardship because of risk it could be used to smuggle contraband, conceal the identity of the wearer, or be used against prison employees in an attack); EEOC v. Oak-Rite Mfg. Corp., No. IP99-1962-C-H/G, 2001 WL 1168156, at *7 (S.D. Ind. Aug. 27, 2001) (exemption from manufacturer's pants-only policy constituted undue hardship by restricting mobility and flexibility and by increasing risk of entanglement).

12 See Dallan F. Flake, Image Is Everything: Corporate Branding and Religious Accommodation in the Workplace, 163 U. PA. L. REV. 699, 725-32 (2015) ; see also, e.g., Cloutier v. Costco Wholesale Corp., 390 F.3d 126, 136 (1st Cir. 2004) (exempting cashier from no-facial-jewelry policy constituted undue hardship by detracting from the "neat, clean and professional image" the employer aimed to cultivate); Anderson v. U.S.F. Logistics (IMC), Inc., 274 F.3d 470, 476-77 (7th Cir. 2001) (allowing employee to use the phrase "Have a Blessed Day" in written communications with customers constituted undue hardship by jeopardizing employer's relationship with its biggest customer); EEOC v. Sambo's of Ga., Inc., 530 F. Supp. 86, 90 (N.D. Ga. 1981) (exempting applicant from nobeard policy constituted undue hardship by adversely affecting employer's public image "as a consequence of offending certain customers and diminishing the 'clean cut' image of the restaurant and its personnel").

13 See Hardison, 432 U.S. at 87-89 (Marshall, J., dissenting) (explaining that all accommodations entail unequal treatment by definition); EEOC v. JBS USA, LLC, No. 8:10CV318, 2013 WL 6621026, at *17 (D. Neb. Oct. 11, 2013) ("[A]lmost any religious accommodation will inevitably cause some differences in treatment among employees.”). 
Most courts acknowledge an employer can deny a religious accommodation that imposes more than a de minimis burden on coworkers. ${ }^{14}$ Courts routinely strike down accommodations that require other employees to involuntarily swap shifts, ${ }^{15}$ take on additional job duties, ${ }^{16}$ or that would jeopardize workplace safety. ${ }^{17}$ But when the primary cost of an accommodation is lowered morale, courts are less consistent in their willingness to accept this as a legitimate hardship. ${ }^{18}$ Even the Supreme Court appears somewhat conflicted, declaring in one case that " [i]f relief under Title VII can be denied merely because the majority group of employees, who have not suffered discrimination, will be unhappy about it, there will be little hope of correcting the wrongs to which the Act is directed," 19 but later striking down a statute exempting religious employees from working on their chosen Sabbath because the law ignored "the convenience or interests of [those] ... employees who do not observe a Sabbath." 20 Such inconsistency

${ }^{14}$ E.g., Harrell v. Donahue, 638 F.3d 975, 980 (8th Cir. 2011) (““[A]n accommodation creates an undue hardship if it causes more than a de minimis impact on co-workers."); Lizalek v. Invivo Corp., 314 F. App'x 881, 882-83 (7th Cir. 2009) (the law does not "insist upon accommodation that would cause more than minimal hardship to the employer or other employees"); Noesen v. Med. Staffing Network, Inc., 232 F. App'x 581, 584-85 (7th Cir. 2007) ("[A]n accommodation that requires other employees to assume a disproportionate workload (or divert them from their regular work) is an undue hardship."). But see Crider v. Univ. of Tenn., Knoxville, 492 F. App'x 609, 614 (6th Cir. 2012) ("Title VII does not exempt accommodation which creates undue hardship on the employees; it requires reasonable accommodation "without undue hardship on the conduct of the employer's business."') (quoting 42 U.S.C. § 2000e(j) (2012)).

${ }^{15}$ See, e.g., Harrell, 638 F.3d at 981 (exempting post officer from Saturday deliveries caused undue hardship by depriving coworkers of their rights under longstanding seniority system); EEOC v. Firestone Fibers \& Textiles Co., 515 F.3d 307, 319 (4th Cir. 2008) (undue hardship to exempt lab technician from Saturday shifts because coworkers would be forced to work overtime and undesirable weekend shifts).

${ }^{16}$ See, e.g., EEOC v. Thompson Contracting, Grading, Paving, \& Utils., Inc., 499 F. App'x 275, 283 (4th Cir. 2012) (allowing dump-truck driver to take Saturdays off when all other drivers were required to work constituted undue hardship by forcing coworkers to "pick up the slack" caused by his absence); Noesen, 232 F. App'x at 584-85 (exempting pharmacist from handling birth control prescriptions constituted undue hardship because coworkers would have to assume disproportionate workload).

${ }^{17}$ See, e.g., Bhatia v. Chevron U.S.A., Inc., 734 F.2d 1382, 1384 (9th Cir. 1984) (employer could not exempt machinist from no-facial-hair policy, in part because coworkers would have to assume his share of potentially hazardous work); Kalsi v. N.Y.C. Transit Auth., 62 F. Supp. 2d 745, 757-60 (E.D.N.Y. 1998) (exempting employee from hard-hat policy would constitute undue hardship, in part because it could endanger coworkers).

${ }^{18}$ See EEOC v. Rent-A-Center, Inc., 917 F. Supp. 2d 112, 119 n.5 (D.D.C. 2013) (acknowledging circuit split as to how readily courts recognize employee morale as a legitimate harm); see also infra Part IV.

${ }^{19}$ Franks v. Bowman Transp. Co., Inc., 424 U.S. 747, 775 (1976) (quoting United States v. Bethlehem Steel Corp., 446 F.2d 652, 663 (2d Cir. 1971)).

${ }^{20}$ Estate of Thornton v. Caldor, Inc., 472 U.S. 703, 709 (1985). 
has produced uneven and confusing case law that offers little practical guidance to employers faced with whether to provide an accommodation that could harm coworker morale.

This Article addresses the conflict that arises when a religious accommodation threatens coworker morale. I argue employee morale is one of an employer's most important assets, as researchers have unequivocally proven morale directly impacts individual and organizational performance. In many ways, employee morale is as important to employers as financial performance, productivity, and safety. Thus, courts must protect morale with the same forcefulness as they do other business outcomes. Part II makes the case for why morale matters by examining factors that affect employee morale, how morale impacts performance, and the various ways a religious accommodation can influence coworker morale. Part III examines how the Supreme Court and the U.S. Equal Employment Opportunity Commission (EEOC) have sought to balance an employer's accommodation duties under Title VII against coworkers' right to perform their jobs free from undue interference. Part IV compares and contrasts the courts' varying approaches to analyzing claims of morale-based hardship. Unsurprisingly, these different methods have generated a muddled case law from which few guiding principles have emerged. Part V offers recommendations for how courts can adequately protect employee morale. These recommendations include distinguishing between valid and invalid reasons why an accommodation threatens morale, accepting harm to employee morale as sufficient to prove undue hardship without requiring further proof of how lowered morale hurts an employer's business, and allowing an employer to establish undue hardship based on the reasonable likelihood an accommodation will harm morale. These changes could allow employers to more easily prove morale-based hardship in appropriate cases, give greater voice to innocent coworkers who otherwise would bear the brunt of an accommodation, and produce a more uniform case law that employers and legal practitioners alike can rely upon in balancing the rights of accommodation seekers with those of other employees.

\section{Why MORALE MATTERS}

Most people are familiar with the term morale based on its wide usage in a variety of contexts. Dwight D. Eisenhower famously declared morale to be "the greatest single factor in successful wars." 21 Morale can have sharply different meanings depending on the setting, ${ }^{22}$ but in general denotes a psychological state of well-being. ${ }^{23}$ In the employment context, morale refers

21 The Military QuOTATION BoOK 144 (James Charlton ed., 1990).

${ }^{22}$ Frederick J. Manning, Morale, Cohesion, and Esprit de Corps, in HANDBOOK OF Military Psychology 453, 454 (Reuven Gal \& A. David Mangelsdorff eds., 1991).

${ }^{23}$ David Bowles \& CARy CoOper, Employee Morale: Driving Performance in Challenging Times 5 (2009). 
to how good employees feel about their work and work environment. ${ }^{24}$ Morale is sometimes used interchangeably with terms such as satisfaction, well-being, engagement, commitment, involvement, passion, empowerment, and enthusiasm. ${ }^{25}$ However, morale is much broader than any single term, encompassing constructs like intrinsic motivation, job satisfaction, work meaningfulness, organizational commitment, and pride in one's work. ${ }^{26}$

Employee morale is dependent upon several factors. Particularly salient is the employee's perception of fairness and equity. ${ }^{27}$ Does management treat all employees equally, or do certain advantages flow based on one's personal connections? Are workplace rules consistently enforced, or are some employees excused from compliance? Are rewards and punishments commensurate with individual conduct, or are some employees treated unreasonably? Other major factors influencing morale include how employees view their organizations and their work, how employees think others see their organizations, compensation and benefits, opportunities for career development and advancement, job security, communication, productivity, working conditions, and decision making. ${ }^{28}$ In short, employee morale is a complex and complicated construct that is influenced by a variety of forces within the workplace. Although no single factor fully accounts for how employees feel about their jobs, fairness and equity play an especially critical role in influencing morale.

\section{A. How Morale Impacts Performance}

For years, employers shied away from morale as a "touchy-feely" subject that seemed too abstract to measure and too insignificant to matter. ${ }^{29}$ This sentiment has largely vanished today thanks to mounting evidence that morale not only correlates with, but actually drives, performance. In fact, the pendulum has swung so far the other way that workplaces often find themselves inundated with opinion surveys, team meetings, focus groups, 360 reviews, open-door policies, and countless other feedback mechanisms designed to measure employee morale. ${ }^{30}$ Indeed, employers have elevated morale from a mere afterthought to "mission critical" and are reaping copious benefits from doing so, as the following studies illustrate.

Morale is one of an organization's most important assets because it impacts performance at both the individual level and for the organization as a

${ }^{24}$ D. Harrison McKnight et al., When Do Feedback, Incentive Control, and Autonomy Improve Morale? The Importance of Employee-Management Relationship Closeness, $13 \mathrm{~J}$. MANAGERIAL ISSUES 466, 467 (2001).

25 BOWLES \& COOPER, supra note 23, at 3.

${ }^{26}$ McKnight et al., supra note 24, at 467.

${ }^{27}$ BOWLES \& COOPER, supra note 23 , at 9.

${ }^{28}$ Id. at 8-9.

${ }^{29}$ See id. at xii.

${ }^{30}$ See id. at 19-27. 
whole. Work is the single activity occupying most people's waking time, so it is hardly surprising that workplace pressures and strains affect both mental and physical health. For example, a meta-analysis of almost 500 studies incorporating over 250,000 employees found positive and highly statistically significant correlations between job satisfaction and mental health indicators such as anxiety, burnout, depression, self-esteem, strain, and general mental health. ${ }^{31}$ In terms of physical health, several studies conclude that employees who rate their bosses negatively or perceive their workplaces as unjust are more likely to suffer from heart disease. ${ }^{32}$ A study of healthcare assistants found workers' blood pressure was significantly higher on days they reported to supervisors they perceived as unfavorable. ${ }^{33}$ On days they reported to favored supervisors, their drop in blood pressure was even greater than when they were at home. ${ }^{34}$ Not surprisingly, the mental and physical consequences of low morale carry over to the workplace. Employees with low morale perform worse in their jobs, ${ }^{35}$ miss more work, ${ }^{36}$ and are more likely to quit ${ }^{37}$ than employees with high morale. They are also less engaged, not as willing to work hard, less committed to the organization's goals, and unlikely to be an advocate for the organization with outsiders. ${ }^{38}$

${ }^{31}$ EB Faragher et al., The Relationship Between Job Satisfaction and Health: A MetaAnalysis, 62 OcCuPATIONAL \& ENVTL. MED. 105, 111 (2005).

${ }^{32}$ Mika Kivimäki et al., Justice at Work and Reduced Risk of Coronary Heart Disease Among Employees: The Whitehall II Study, 165 ARCHIVES InTERNAL MED. 2245, 2248-49 (2005); Mika Kivimäki et al., Organisational Justice and Change in Justice as Predictors of Employee Health: The Whitehall II Study, 58 J. EPIDEMIOLOGY \& COMMUNITY HeAlTH 931, 933 (2004); A Nyberg et al., Managerial Leadership and Ischaemic Heart Disease Among Employees: The Swedish WOLF Study, 66 Occupational \& EnVtL. Med. 51, 55 (2009).

${ }^{33} \mathrm{~N}$ Wager et al., The Effect on Ambulatory Blood Pressure of Working Under Favourably and Unfavourably Perceived Supervisors, 60 Occupational \& ENVTL. Med. 468, 472 (2003).

${ }^{34}$ Id.

${ }^{35}$ Michael Riketta, Attitudinal Organizational Commitment and Job Performance: A Meta-Analysis, 23 J. ORganizAtional BeHAV. 257, 260 (2002) (performing a metaanalysis based of 111 samples from ninety-three published studies); Timothy A. Judge et al., The Job Satisfaction-Job Performance Relationship: A Qualitative and Quantitative Review, 127 PSYCHOL. Bull. 376, 385 (2001).

${ }^{36}$ Corné A. M. Roelen et al., Job Satisfaction and Sickness Absence: A Questionnaire Survey, 58 Occupational Med. 567, 569 (2008); Jan F. Ybema et al., Antecedents and Consequences of Employee Absenteeism: A Longitudinal Perspective on the Role of Job Satisfaction and Burnout, 19 Eur. J. WORK \& ORGANIZATIONAL PSYCHOL. 102, 117 (2010).

${ }^{37}$ Gallup, State of the American WorkPlace 24-26 (2013); Eric G. Lambert et al., The Impact of Job Satisfaction on Turnover Intent: A Test of Structural Measurement Model Using a National Sample of Workers, 38 Soc. SCI. J. 233, 245 (2001); Robert D. Mohr \& Cindy Zoghi, High-Involvement Work Design and Job Satisfaction, 61 Indus. \& LAB. REL. REV. 275, 275 (2008).

${ }^{38}$ See BOWLES \& COOPER, supra note 23, at 59. 
At the organizational level, high-morale companies are known to perform better than their competitors. ${ }^{39}$ A recent Gallup study of forty-nine publicly traded companies found organizations with a critical mass of engaged employees experienced 147 percent higher earnings per share compared with their competition. ${ }^{40}$ Similarly, researchers have found a positive correlation between employee attitudes and both return on assets and earnings per share. ${ }^{41}$ In addition to stronger financial performance, high-morale workplaces benefit from greater productivity, ${ }^{42}$ fewer absences, ${ }^{43}$ less stress, ${ }^{44}$ lower accident rates ${ }^{45}$ and greater employee retention. ${ }^{46}$ Researchers also have established a positive relationship between employee morale and customer satisfaction and loyalty. ${ }^{47}$ Furthermore, David Bowles and Carey Cooper argue employee

39 See David H. Maister, Practice What You Preach: What Managers Must Do to Create a High Achievement Culture 77-84 (2001); David Sirota ET AL., The EnTHUSIASTIC EMPlOYEE 33-53 (2005); Alex Edmans, Does the Stock Market Fully Value Intangibles? Employee Satisfaction and Equity Prices, 101 J. FIN. ECON. 621, 634 (2011); James R. Evans \& Eric P. Jack, Validating Key Results Linkages in the Baldrige Performance Excellence Model, 10 QuALITY MgMT. J. 7 (2003); James K. Harter et al., Business-Unit-Level Relationship Between Employee Satisfaction, Employee Engagement, and Business Outcomes: A Meta-Analysis, 87 J. APPlied Psychol. 268, 276 (2002) (performing a meta-analysis of forty-two studies in thirty-six independent companies); Milé Terziovski \& Danny Samson, The Link Between Total Quality Management Practice and Organisational Performance, 16 InT'L J. Quality \& Reliability MgMt. 226, 236 (1999).

${ }^{40}$ GALLUP, supra note 37, at 26.

${ }^{41}$ Benjamin Schneider et al., Which Comes First: Employee Attitudes or Organizational Financial and Market Performance?, 88 J. APPLIED PSYCHOL. 836, 841 (2003).

${ }^{42}$ Gallup, supra note 37, at 26; Doug Jensen et AL., The MANAGER's Guide to Rewards: What You NeEd TO KNOW TO GET THE Best For-AND From-Your EMPLOYEES 31-44 (2007).

43 See sources cited supra note 36.

44 BOWLES \& COOPER, supra note 23, at 59.

${ }^{45}$ Gallup, supra note 37, at 26; Melvin L. Holcom et al., Employee Accidents: Influences of Personal Characteristics, Job Characteristics, and Substance Use in Jobs Differing in Accident Potential, 24 J. SAFETY RES. 205, 205 (1993); A. Elizabeth Ready et al., Fitness and Lifestyle Parameters Fail to Predict Back Injuries in Nurses, 18 CANADIAN J. Applied Physiology 80, 88 (1993); Oi-ling Siu et al., Safety Climate and Safety Performance Among Construction Workers in Hong Kong: The Role of Psychological Strains as Mediators, 36 ACCIDENT ANALYSIS \& PREVENTION 359, 365 (2004).

${ }^{46}$ See sources cited supra note 37 . Retention is critical for a number of reasons, not least of which is the cost of replacing an employee, which can range between 1.5 and 2.5 times the departing employee's annual salary. See WAYNE F. CAscio, MAnAging Human RESOURCES 53-57 (8th ed. 2010).

${ }^{47}$ BOWLES \& COOPER, supra note 23 , at 59, 109-26; GALluP, supra note 37 , at 25; Frank J. Smith, Organizational Surveys: The Diagnosis and Betterment of Organizations Through Their Members 57-61 (2003); Jack W. Wiley \& Scott M. Brooks, The High-Performance Organizational Climate, in HANDBOOK OF Organizational Culture \& Climate 177, 186-87 (Neal M. Ashkanasy et al. eds., 2000); Kenneth L. Bernhardt et al., A Longitudinal Analysis of Satisfaction and 
morale benefits organizations in more subtle ways that are not easily measurable. ${ }^{48}$ For instance, morale provides companies with a competitive edge in good times and bad, as employees with high morale are more likely to pull together and work as one, share in sacrifices, and advance creative ideas for improvement. ${ }^{49}$ High morale also helps organizations attract and retain talented people, who, having more choice than most by virtue of their talent, will refuse to work in an environment with low morale..$^{50}$ Morale can also support the implementation of organizational strategies, make the workplace easier to manage, reinforce company culture, and help employers work more harmoniously with unions. ${ }^{51}$ Additionally, even the process of measuring employee satisfaction and feeding back the results can boost morale by giving a voice to the lowest-level employee. ${ }^{52}$

In light of the overwhelming research, many companies today place a premium on employee morale. Perhaps nowhere is this more evident than at Google. The internet search giant is widely admired for its outside-the-box employee perks, including free gourmet meals, video games, a rock-climbing wall, salons, gyms, nap pods, free legal advice, generous family leave, pets in the workplace, on-site daycare, and even indoor slides. ${ }^{53}$ Additionally, Google asks its employees to devote up to twenty percent of their time at work to personal projects. ${ }^{54}$ According to Google, these perks are specifically designed to bolster employee morale:

Profitability, 47 J. Bus. RES. 161, 163 (2000); Mark Norquist et al., A Great Place to Shop, Work and Invest: Measuring and Managing the Service Profit Chain at Sears Canada, 3 INTERACTIVE MARKETING 255, 256 (2002); Terziovski \& Samson, supra note 39, at 236.

48 BOWLES \& COOPER, supra note 23 , at 60-65.

${ }^{49} \mathrm{Id}$. at $60-61$.

${ }^{50} \mathrm{Id}$. at $62-63$.

${ }^{51} I d$. at $61-65$.

52 Id. at $61-62$.

53 See Benefits, GooGLE, www.google.com/about/careers/lifeatgoogle/benefits/ (last visited Jan. 18, 2015), archived at http://perma.cc/7U2G-ZE5X; Yvonne Humphries, How Google's Perks Alleviate Stress and Boost Employees' Morale, HR REV. (June 19, 2014), www.hrreview.co.uk/analysis/analysis-reward/how-googles-perks-alleviate-stress-and-boo st-employees-morale, archived at http://perma.cc/V9XM-ANJR; Nap Pods, Massages, Swimming Pools and Dance Class: How Google Interns Are Pampered with Long List of Perks, NY DAILY NEWS (June 10, 2014, 3:41 PM), www.nydailynews.com/lifestyle/google-interns-treated-long-list-perks-article-1.1824258, archived at http://perma.cc/ EKH7-8R2T; Inside Google Workplaces, From Perks to Nap Pods, CBS News (Jan. 22, 2013, 10:53 AM), www.cbsnews.com/news/inside-google-workplaces-from-perks-to-nappods/, archived at http://perma.cc/7SH2-VP4Y; Matt Lynley, RANKED: The Best Slides and Worst Slides in Google's Offices, Bus. INSIDER (May 14, 2012, 2:04 PM), www.businessinsider.com/googles-office-slides-2012-5?op=1, archived at http://perma.cc/XN58-WAGQ.

${ }^{54}$ Amy Gesenhues, Google Says 20\% Time Is Still Core Part of Company Culture, MARKETING LAND (Aug. 16, 2013, 7:08 PM), www.marketingland.com/google-employeesare-debating-if-20-time-policy-still-exists-55955, archived at http://perma.cc/S68N-RZEL. 
Here's the secret sauce to our benefits and perks: It's all about removing barriers so Googlers can focus on the things they love, both inside and outside of work. We're constantly searching for unique ways to improve the health and happiness of our Googlers. And it doesn't stop there-our hope is that, ultimately, you become a better person by working here. ${ }^{55}$

Although perhaps extreme, Google's fanatical attention to morale has clearly paid off. Fortune Magazine named Google the best company to work for in 2015-its sixth time receiving this honor. ${ }^{56}$ Not surprisingly, many organizations look to Google for inspiration in finding ways to attract and retain talented workers. ${ }^{57}$

\section{B. How Religious Accommodations Affect Morale}

The relationship between religious accommodations and employee morale is undoubtedly complex. On the one hand, employees seem to experience higher job satisfaction when employers adopt an accommodation mindset and implement policies addressing religious diversity. ${ }^{58}$ Thus, it is entirely plausible some religious accommodations may actually boost morale when employees see their employers practice what they preach-especially if the accommodation is unlikely to directly impact other workers, such as allowing a Muslim employee to wear a headscarf despite a no-headgear policy or creating an otherwise unused space for employees to pray or meditate. However, it is not hard to imagine that any goodwill that accommodationfriendly policies generate could quickly dissipate when an accommodation

55 See Benefits, supra note 53.

56100 Best Companies to Work for 2015, FORTUNE, http://fortune.com/bestcompanies/ (last visited Mar. 30, 2015), archived at http://perma.cc/29KV-T4XB.

${ }^{57}$ See, e.g., Martha Mendoza, Tech Firms Offering More Perks to Recruit, Retain Talent, HufFington Post (May 31, 2013, 5:12 AM), www.huffingtonpost.com/ 2013/03/31/tech-firms-increase-office-perks_n_2988687.html, archived at http://perma.cc/ EK6X-TC28; How to Attract and Retain Generation Y Employees, TEMPSTAFF (May 18, 2012), www.tempstaff.net/2012/05/18/how-to-attract-and-retain-generation-y-employees/, archived at http://perma.cc/772U-K5L6.

58 See Joyce Dubensky, TANENBAUM CENTER FOR INTERRELIGIOUS UNDERSTANDING, What AMERICAN Workers REALly THINK ABOUt RELIGION: TANENBAUM's 2013 SURVEY OF AMERICAN WORKERS AND RELIGION, in EMPLOYMENT DISCRIMINATION LAW \& LitigATION 2014 18-19 (Practising Law Institute 2013). According to this study, employees at companies without clear processes for handling worker complaints are nearly twice as likely to be looking for a new job (41 percent to 22 percent) and are far more likely to say they do not look forward to coming to work ( 35 percent to 15 percent) as workers who say their companies do have these processes. Id. Employees at companies that do not permit personal days to be used for any reason are more likely to say they are looking for a new job (35 percent to 24 percent), whereas employees at companies that do not provide flexible hours for religious observance are more than twice as likely to say they do not look forward to coming to work (29 percent to 13 percent). Id. 
negatively impacts other employees. ${ }^{59}$ For instance, an individual may agree in principle with a policy allowing employees to take work off for religious holidays but later resent having to perform extra job duties in place of absent employees on those days.

When an accommodation burdens other employees, their morale may be hurt due to what they perceive as a lack of organizational justice. Perceptions of fairness are often accompanied by emotional reactions that can influence job performance. ${ }^{60}$ According to equity theory, employees evaluate the exchange relationships with their employers in terms of a ratio between the effort the employees spend and the rewards they receive. ${ }^{61}$ When employees perceive inequity based on discrepancies in their effort-to-reward ratio, they experience an unpleasant emotional state. ${ }^{62}$ To reduce this tension, employees often will attempt to alter or reframe efforts and rewards, withdraw from the job, or change comparison dimensions. ${ }^{63}$ In other words, when employees believe employers act fairly, they experience beneficial boosts in morale which in turn increase their likelihood of reciprocating in kind with behaviors desired by employers. ${ }^{64}$ But when employees believe their employers have acted unfairly, they suffer a decrease in morale that can subsequently lead to behaviors that harm employers. ${ }^{65}$

Even if a religious accommodation does not directly impact other employees, their morale may still suffer if they disagree with the accommodation for some other reason. For example, an employee may become upset or disgruntled if the employer allows a Sikh employee to wear a beard despite the company's no-facial-hair policy. This accommodation would not have any direct impact on the other employee, yet that employee may still feel angry either because he finds Sikhism objectionable or believes it would

${ }^{59}$ See, e.g., EEOC v. Firestone Fibers \& Textiles Co., 515 F.3d 307, 318 (4th Cir. 2008) (noting that although employees claimed they had no problem covering the plaintiff's absences, "it was reasonable for Firestone to be concerned that such feelings would not be long-lived").

${ }^{60}$ Laurie J. Barclay et al., Exploring the Role of Emotions in Injustice Perceptions and Retaliation, 90 J. APPLIED PsyCHOL. 629, 634 (2005).

61 Onne Janssen, Fairness Perceptions as a Moderator in the Curvilinear Relationships Between Job Demands, and Job Performance and Job Satisfaction, 44 ACAD. MGMT. J. 1039, 1041 (2001).

62 Id.

$63 \mathrm{Id}$.

${ }^{64}$ See Lynn M. Shore et al., The Employee-Organization Relationship: A Timely Concept in a Period of Transition, in 23 RESEARCH In PERSONNEL AND HuMAN RESOURCES MANAGEMENT 291 (Joseph J. Martocchio ed., 2004); Christopher C. Rosen et al., Perceptions of the Organizational Context and Psychological Contract Breach: Assessing Competing Perspectives, 108 Organizational Behav. \& Hum. Decision Processes 202, 213 (2009); Amanuel G. Tekleab et al., Extending the Chain of Relationships Among Organizational Justice, Social Exchange, and Employee Reactions: The Role of Contract Violations, 48 ACAD. MGMT. J. 146, 153 (2005).

${ }^{65}$ See BOWLES \& COOPER, supra note 23, at 9. 
be unfair for the employer to make an exception to its policy. ${ }^{66}$ Although courts should not accept either of these reasons as a valid basis for denying a religious accommodation, ${ }^{67}$ the fact remains that occasionally employee morale can be hurt even when an accommodation has no direct impact on other workers.

In short, the importance of employee morale is difficult to overstate. Morale impacts both individual and organizational performance, affecting everything from absenteeism to a company's bottom line. Because a religious accommodation necessarily entails preferential treatment of one employee over another, there is a risk other employees may perceive the accommodation as unjust or unfair, resulting in a decrease in morale. Therefore, courts must be especially sensitive to coworker morale concerns to ensure employers do not take on greater hardship than Title VII requires.

\section{COWORKER RIGHTS UNDER TITLE VII}

A major reason courts struggle with religious accommodations that threaten coworker morale is because the law itself is practically silent on this issue. The text of Title VII makes no mention of morale, ${ }^{68}$ nor has the Supreme Court ever decided a case involving a morale-based hardship. However, the statute does reference coworker rights more generally, and the Supreme Court has decided a handful of cases involving coworker rights in relation to Title VII remedies. ${ }^{69}$ Additionally, the EEOC has issued multiple publications addressing religious accommodations that adversely affect other employees. Important guiding principles can be gleaned from these more general references that are helpful in understanding the relationship between religious accommodations and coworker morale.

\section{A. Statutory Background}

Title VII prohibits employers from failing or refusing to hire, discharging, or otherwise discriminating against any individual "with respect to his compensation, terms, conditions, or privileges of employment, because of such individual's race, color, religion, sex, or national origin." ${ }^{0}$ Courts initially interpreted Title VII as prohibiting only status-based discrimination rather than

\footnotetext{
${ }^{66}$ See Lisa E. Key, Co-Worker Morale, Confidentiality, and the Americans with Disabilities Act, 46 DePAul L. REV. 1003, 1009-11 (1997).

67 See infra Part V.A.

68 See, e.g., 42 U.S.C. $\S 2000 \mathrm{e}-2$ (2012).

${ }^{69}$ See 42 U.S.C. $\$ 2000 \mathrm{e}-2(\mathrm{~b})$.

7042 U.S.C. $\$ 2000 \mathrm{e}-2(\mathrm{a})(1)$. Additionally, state laws prohibiting religious discrimination in employment largely track the language of Title VII, though several contain important differences. See, e.g., OR. REV. STAT. § 659A.033(4) (exempting an employer from providing a religious accommodation only "if the accommodation requires significant difficulty or expense").
} 
imposing any affirmative obligation on employers. ${ }^{71}$ Thus, an employer could not take an adverse action against an employee because of his religion but likewise had no duty to accommodate the employee in exercising his religious beliefs. This proved problematic for employees whose beliefs prohibited them from working on the Sabbath or religious holidays. Although Title VII protected such employees from adverse action because of their religious beliefs, the absence of any duty to accommodate meant employers were free to terminate them based on their refusal to work certain shifts. In essence, this allowed employers to end-run Title VII by discharging religious employees for ostensibly nonreligious reasons. ${ }^{72}$

Congress attempted to close this loophole in 1972 by amending Title VII to impose an affirmative obligation on employers to provide a religious accommodation "unless an employer demonstrates that he is unable to reasonably accommodate to an employee's or prospective employee's religious observance or practice without undue hardship on the conduct of the employer's business." 73 Congress declined to define "reasonably accommodate" or "undue hardship," instead punting this task to the courts. ${ }^{74}$ The amendment likewise does not explicitly address whether an employer can deny an accommodation because of its potential impact on coworkers. One important clue in this regard is found in Title VII's seniority-system exemption, which authorizes employers to apply different terms and conditions of employment pursuant to a bona fide seniority or merit system, so long as the intent of such system is not discriminatory. ${ }^{75}$ By carving out this

${ }^{71}$ Rachel M. Birnbach, Note, Love Thy Neighbor: Should Religious Accommodations that Negatively Affect Coworkers' Shift Preferences Constitute an Undue Hardship on the Employer Under Title VII?, 78 FORDHAM L. REV. 1331, 1336-37 (2009).

72 This was precisely the scenario at issue in Dewey v. Reynolds Metals Co., 429 F.2d 324 (6th Cir. 1970), a highly controversial case in which the Sixth Circuit held that the employer did not violate Title VII by terminating an employee who refused to work mandatory Sunday shifts because of his religious beliefs. Id. at 329. When the Supreme Court subsequently affirmed the decision by an equally-divided court, Dewey v. Reynolds Metals Co., 402 U.S. 689 (1971), Congress responded to public outcry by amending Title VII to require religious accommodations absent undue hardship. See James A. Sonne, The Perils of Universal Accommodation: The Workplace Religious Freedom Act of 2003 and the Affirmative Action of 147,096,000 Souls, 79 Notre DAME L. REV. 1023, 1038 (2004); see also 118 CONG. REC. 7167 (1972) (explaining the purpose of amending Title VII was "to provide the statutory basis for EEOC to formulate guidelines on discrimination because of religion such as those challenged in Dewey v. Reynolds Metals Company").

7342 U.S.C. $\$ 2000 \mathrm{e}(\mathrm{j})(2012)$.

74 See Trans World Airlines, Inc. v. Hardison, 432 U.S. 63, 74-75 (1977) (noting that Title VII "provides no guidance for determining the degree of accommodation that is required of an employer," as the precise "reach of that obligation has never been spelled out by Congress").

7542 U.S.C. $\$ 2000 \mathrm{e}-2(\mathrm{~h})$ (2012). Courts often rely on this provision to strike down religious accommodations that interfere with an employer's seniority system. See, e.g., Hardison, 432 U.S. at 81-82; Harrell v. Donahue, 638 F.3d 975, 981-82 (8th Cir. 2011); 
exception, Congress acknowledged an employee's right to be free from workplace discrimination does not automatically trump the rights of other workers. Although this provision is limited to coworker rights under a seniority or merit system, it nonetheless signals that in some situations it is necessary to weigh an employee's right to an accommodation against the rights and expectations of other workers.

Although Title VII's religious accommodation provision has remained unchanged since its enactment, Congress has considered at least sixteen amendments to the law designed to make it more difficult for employers to prove undue hardship. ${ }^{76}$ The most recent proposed legislation, the Workplace Religious Freedom Act of 2013, sought to require employers to provide certain religious accommodations unless they could prove the accommodation would cause "significant difficulty or expense on the conduct of the employer's business." 77 Like its predecessors, the Act failed to garner the support necessary and died in committee. ${ }^{78}$ If and when such legislation eventually passes, employers will have a more difficult time proving a religious accommodation would cause undue hardship. Not only will employers bear a heavier burden in accommodating religious beliefs, but coworkers, too, will be expected to tolerate greater changes to their own employment as a result of religious accommodations that would almost certainly become more common and extreme in the future. The impact this heightened burden could have on employee morale and, consequently, performance, is cause for concern for employers.

\section{B. Supreme Court Analysis of Coworker Rights}

Although the Supreme Court has never addressed religious accommodations that threaten employee morale, it has decided a handful of cases involving coworker rights more generally that are insightful. The only case the Supreme Court has decided that involves how a religious accommodation would impact coworkers is Trans World Airlines, Inc. v.

Sides v. NYS Div. of State Police, No. 03-CV-153, 2005 WL 1523557, at*5 (N.D.N.Y. June 28, 2005).

${ }^{76}$ See S. 3686, 112th Cong. (2012); S. 4046, 111th Cong. (2010); S. 3628, 110th Cong. (2008); H.R. 1431, 110th Cong. (2007); H.R. 1445, 109th Cong. (2005); S. 677, 109th Cong. (2005); S. 893, 108th Cong. (2003); S. 2572, 107th Cong. (2002); H.R. 4237, 106th Cong. (2000); S. 1668, 106th Cong. (1999); H.R. 2948, 105th Cong. (1997); S. 1124, 105th Cong. (1997); S. 92, 105th Cong. (1997); H.R. 4117, 104th Cong. (1996); S. 2071, 104th Cong. (1996); H.R. 5233, 103d Cong. (1994).

${ }^{77}$ Workplace Religious Freedom Act of 2013, S. 3686, 112th Cong. $\S \S 4(\mathrm{a})(2)-(3)$ (2012).

${ }^{78}$ See S. 3686 (112th): Workplace Religious Freedom Act of 2013, GovTrACK, https://www.govtrack.us./congress/bills/112/s3686\#overview (last visited Mar. 30, 2015), archived at http://perma.cc/73T4-KWKN (stating that the bill was referred to the House Committee on Health, Education, labor, and Pensions in late 2012, and there have been no subsequent votes). 
Hardison. ${ }^{79}$ Larry Hardison worked as a clerk for Trans World Airlines (TWA) in a department that operated around the clock. ${ }^{80} \mathrm{He}$ and his coworkers bid for shifts in accordance with the seniority system contained in the applicable collective bargaining agreement. ${ }^{81}$ After joining the Worldwide Church of God, Hardison informed TWA he could no longer work Saturdays due to his religious beliefs. ${ }^{82}$ This presented a problem because Hardison did not have enough seniority to bid for a shift with Saturdays off. ${ }^{83}$ TWA considered various potential accommodations, including allowing Hardison to work a four-day workweek or swap shifts with another worker, but ultimately concluded these options were infeasible. ${ }^{84}$ Hardison was fired for insubordination based on his refusal to work Saturdays and thereafter brought suit challenging TWA's actions. ${ }^{85}$

In siding with TWA, the Supreme Court focused primarily on whether it was reasonable to expect the company to arrange a shift swap between Hardison and other employees, even though this would have violated the collective bargaining agreement and the seniority rights of other employees. ${ }^{86}$ The Court determined this constituted an undue hardship, both because it would have forced TWA to breach the bargaining agreement, and because it would hurt other employees by depriving them of their shift preferences because they did not adhere to a religion that prohibited Saturday work. ${ }^{87}$ The Court declared that Title VII does not contemplate this type of unequal treatment, as the statute prohibits discrimination directed against majorities as well as minorities, and further reasoned:

It would be anomalous to conclude that by "reasonable accommodation" Congress meant that an employer must deny the shift and job preference of some employees, as well as deprive them of their contractual rights, in order to accommodate or prefer the religious needs of others, and we conclude that Title VII does not require an employer to go that far. ${ }^{88}$

${ }^{79}$ Trans World Airlines, Inc. v Hardison, 432 U.S. 63 (1977). The only other religious accommodation case the Supreme Court has decided is Ansonia Board of Education v. Philbrook, 479 U.S. 60 (1986). The issue in Philbrook was not whether the accommodation unduly burdened coworkers, but whether the employer had to accept the plaintiff's preferred accommodation absent proof of undue hardship. Id. at 66 . Consequently, Philbrook is unhelpful in understanding the relationship between religious accommodations and coworker rights.

${ }^{80}$ Hardison, 432 U.S. at 66-67.

$81 \mathrm{Id}$. at 67.

${ }^{82} I d$. at $67-68$

${ }^{83} \mathrm{Id}$. at 68 .

${ }^{84} \mathrm{Id}$. at $68-69$.

$85 \mathrm{Id}$. at 69.

${ }^{86}$ Hardison, 432 U.S. at 76-85.

${ }^{87} \mathrm{Id}$. at $80-81$.

${ }^{88} \mathrm{Id}$. at 81 . 
This oft-cited passage makes clear an employer cannot be required to provide a religious accommodation that interferes with the shift and job preferences of coworkers or otherwise deprives them of contractual rights, but leaves open the question of whether noncontractual aspects of employment such as morale can also trump an employee's right to an accommodation.

The Court also considered whether it was reasonable to require TWA to accommodate Hardison by allowing him to work a four-day week, utilizing in his absence either a coworker on duty elsewhere or other available employees through the payment of overtime wages ${ }^{89}$ Both alternatives involved costs to TWA, either in the form of lost efficiency or higher wages. ${ }^{90}$ In perhaps the most famous line from the decision, the Court proclaimed that " $[\mathrm{t}] \mathrm{o}$ require TWA to bear more than a de minimis cost in order to give Hardison Saturdays off is an undue hardship." 91 Thus, the Court set the evidentiary threshold for an employer to prove undue hardship at the lowest level possible. ${ }^{92}$ The Court explained that requiring TWA to bear additional costs to give Hardison Saturdays off when no such costs are incurred to give other employees the days off they want would involve unequal treatment of employees based on religion. ${ }^{93}$ Finding nothing in the statutory language or legislative history to the contrary, the Court refused to construe Title VII as requiring an employer to discriminate against some employees in order to enable others to observe their Sabbath. ${ }^{94}$

As the only Supreme Court case to address religious accommodations that adversely impact coworker rights, Hardison typically serves as the starting point for lower courts considering this issue. There is disagreement among courts as to how to interpret Hardison. Some courts read the decision narrowly as mainly applicable to religious accommodations that interfere with other employees' contractual rights. ${ }^{95}$ Other courts read Hardison more expansively

${ }^{89}$ Id. at 84 .

${ }^{90} \mathrm{Id}$.

$91 \mathrm{Id}$.

92 Translated from Latin, "de minimis" means "of the least." BLACK'S LAW DiCTIONARY 524 (10th ed. 2014). Black's Law Dictionary defines "de minimis" as "trifling, negligible," and "so insignificant that a court may overlook it in deciding an issue or case." Id. Courts characterize the de minimis standard as "not a heavy burden," "minimal," "very low," "extremely low," and "neither onerous, nor intended to be rigid, mechanized or ritualistic." See, e.g., Faul v. Potter, 355 F. App'x. 527, 528-29 (2d Cir. 2009); Beyer v. Cnty. of Nassau, 524 F.3d 160, 163 (2d Cir. 2008); Dupree v. UHABSterling St. Hous. Dev. Fund Corp., No. 10-CV-1894, 2012 WL 3288234, at *4 (E.D.N.Y. Aug. 10, 2012); Franklin v. Astrue, No. C11-1615-MJP-MAT, 2012 WL 3059407, at *2 (W.D. Wash. July 25, 2012); Cannon v. Burkybile, No. 99C4623, 2002 WL 448988, at*9 (N.D. Ill. Mar. 22, 2002).

93 Hardison, 432 U.S. at 84.

94 Id. at 85 .

95 See, e.g., Opuku-Boateng v. California, 95 F.3d 1461, 1470 (9th Cir. 1996); Jacobs v. Scotland Mfg., Inc., No. 1:10CV814, 2012 WL 2366446, at *9 (M.D.N.C. June 21, 2012). 
to mean an employer can establish undue hardship if an accommodation would impose any burden on coworkers that is more than de minimis, regardless of whether such burden is related to other employees' contractual rights. ${ }^{96}$ Consequently, a court's willingness to recognize a morale-based hardship often depends, in part, on how broadly it construes Hardison.

Outside the religious accommodation context, the Supreme Court has decided two cases in which it considered the effect Title VII remedies would have on other workers. In Franks v. Bowman Transportation Co., decided just one year before Hardison, the Supreme Court showed little concern for coworker rights. ${ }^{97}$ At issue was whether applicants who were denied employment because of their race could be awarded seniority status retroactive to the dates of their employment applications. ${ }^{98}$ The Court rejected the company's argument that such relief was inappropriate because it would conflict with the economic interests of other employees. ${ }^{99}$ The Court acknowledged coworkers' conflicting interests "will, of course, always be present in instances where some scarce employment benefit is distributed among employees on the basis of their status in the seniority hierarchy." 100 But the Court found nothing in Title VII's text or legislative history to indicate Congress intended to bar this form of relief merely because the interests of other employees might be adversely affected. ${ }^{101}$ To the contrary, the Court reasoned that "a sharing of the burden of the past discrimination is presumptively necessary," 102 and if relief under Title VII can be denied merely because coworkers would be unhappy about it, "there will be little hope of correcting the wrongs to which the Act is directed." 103 The Court's use of the word "unhappy" is curious because the employer did not claim it was the coworkers' happiness, but rather their seniority, that was at stake. That the Court made the logical connection between seniority and happiness is significant, but somewhat overshadowed by the Court's pronouncement that remedial relief under Title VII trumps coworker happiness.

96 See, e.g., Harrell v. Donahue, 638 F.3d 975, 982 (8th Cir. 2011) (a religious accommodation that deprives other workers of seniority rights constitutes undue hardship "irrespective of whether the seniority system was established under a collective bargaining agreement or whether it was unilaterally imposed by an employer"); Weber v. Roadway Express, Inc., 199 F.3d 270, 273 (5th Cir. 2000) (the fact that the plaintiff's coworkers had no contract entitling them to particular job preferences did not render Hardison inapplicable).

${ }^{97}$ Franks v. Bowman Transp. Co., 424 U.S. 747 (1976).

98 Id. at 750.

${ }^{99} \mathrm{Id}$. at $773-79$.

${ }^{100} \mathrm{Id}$. at 774 .

${ }^{101}$ Id. at $774-75$.

102 Id. at 777 .

103 Franks, 424 U.S. at 775 (quoting United States v. Bethlehem Steel Corp., 446 F.2d 652, 663 (2d Cir. 1971)). 
Just one year later, the Supreme Court softened its position with its decisions in Hardison ${ }^{104}$ and International Brotherhood of Teamsters $v$. United States. ${ }^{105}$ In Teamsters, the Court again faced the question of whether a class of discrimination victims was entitled to retroactive seniority under Title VII. ${ }^{106}$ This time the Court took a more measured approach in considering the potential impact the remedy would have on other employees:

Although not directly controlled by the Act, the extent to which the legitimate expectations of nonvictim employees should determine when victims are restored to their rightful place is limited by basic principles of equity. In devising and implementing remedies under Title VII, no less than in formulating any equitable decree, a court must draw on the qualities of mercy and practicality [that] have made equity the instrument for nice adjustment and reconciliation between the public interest and private needs as well as between competing private claims. Especially when immediate implementation of an equitable remedy threatens to impinge upon the expectations of innocent parties, the courts must look to the practical realities and necessities inescapably involved in reconciling competing interests, in order to determine the special blend of what is necessary, what is fair, and what is workable. 107

The Court's shift in tone from just one year earlier is remarkable. Its seemingly newfound sympathy for coworkers is evident in its characterization of such persons as "nonvictims" and "innocent parties." It may also be significant that the Court referenced the "expectations" of coworkers rather than their contractual rights, suggesting the noncontractual rights of third parties also merit consideration. As in Hardison, the Court acknowledged that the rights of Title VII plaintiffs are not absolute, but instead must be balanced with the rights and expectations of coworkers in reaching an equitable resolution.

The Supreme Court's growing concern for coworker rights and expectations was again apparent in Estate of Thornton v. Caldor, Inc. ${ }^{108}$ Unlike the previous cases, Caldor did not involve a claim under Title VII, but rather a constitutional challenge to a Connecticut statute that granted Sabbath observers the unqualified right to not work on their chosen Sabbath. ${ }^{109}$ The Court struck down the statute, in part because it took "no account of the convenience or interests of the employer or those of other employees who do not observe a Sabbath" and instead mandated that Sabbath religious concerns automatically trump secular interests in the workplace. ${ }^{110}$ The Court noted that

104 See Trans World Airlines, Inc. v. Hardison, 432 U.S. 63 (1977).

105 See Int'1 Bhd. Teamsters v. United States, 431 U.S. 324 (1977).

106 Id. at 328 .

${ }^{107} I d$. at 374-75 (alteration in original) (citation omitted) (internal quotation marks omitted).

108 See Estate of Thornton v. Caldor, Inc., 472 U.S. 703 (1985).

${ }^{109} \mathrm{Id}$. at $704-05$.

${ }^{110}$ Id. at $708-11$. 
to avoid an Establishment Clause violation, the statute needed to protect employers and other employees from undue hardship by carving out an exemption "when honoring the dictates of Sabbath observers would cause the employer substantial economic burdens or when the employer's compliance would require the imposition of significant burdens on other employees required to work in place of the Sabbath observers." 111 Once again, the Supreme Court stressed the importance of striking the appropriate balance between the rights of religious employees, their employers, and other employees.

Even though the Supreme Court has never directly addressed the issue of employee morale in the context of religious accommodations, the foregoing cases illustrate an increasing recognition by the high court that coworker rights are important. But how much coworker morale matters remains a question of debate in courtrooms and workplaces throughout the nation. Hardison, Franks, and Teamsters involved religious accommodations or remedial relief that would interfere with other employees' contractual seniority rights, whereas Caldor involved unspecified concerns about coworker well-being. ${ }^{12}$ Should employers be allowed to deny religious accommodations only if coworkers' contractual rights would be impacted, or does this defense extend to noncontractual rights as well? ${ }^{113}$ If the latter, how does coworker morale factor into the equation?

\section{EEOC Interpretation of Coworker Rights}

As the agency tasked with interpreting Title VII, courts often defer to the EEOC in deciding employment discrimination issues. ${ }^{114}$ The EEOC has authored a number of publications addressing religious accommodations and coworker rights, including its Compliance Manual, two question-and-answer sheets, and the federal regulations. ${ }^{115}$ The Compliance Manual is particularly

${ }^{111}$ Id. at 709-10 (citations omitted).

112 See discussion supra at notes 90-109.

113 See Birnbach, supra note 71, at 1370-73 (arguing an employer should only be able to prove undue hardship if a religious accommodation infringes on coworkers' contractually protected rights, creates an economic burden on the employer, or requires coworkers to take on additional, physically hazardous tasks).

${ }^{114}$ See Fed. Express Corp. v. Holowecki, 552 U.S. 389, 397 (2008) (stating that the EEOC is entitled to deference when it adopts a reasonable interpretation of regulations it has put in force); Kraus v. Presidio Trust Facilities Div./Residential Mgmt. Branch, 572 F.3d 1039, 1045 (9th Cir. 2009) (deferring to EEOC interpretation).

115 U.S. EQuAl EMP. OpPortunity COMM’n, COMPLiance MANUAL (2008), available at http://www.eeoc.gov/policy/docs/religion.pdf, archived at http://perma.cc/MJ5WDZYF; Questions and Answers About the Workplace Rights of Muslims, Arabs, South Asians, and Sikhs Under the Equal Employment Opportunity Laws, U.S. EQUAL EMP. OPPORTUNITY COMM'N (Mar. 21, 2005), www.eeoc.gov/facts/backlash-employee.html, archived at perma.cc/5ZLZ-Q2DW; Questions and Answers: Religious Discrimination in the Workplace, U.S. EQUAL EMP. OPPORTUNITY COMMISSION (last modified Jan. 31, 2011), 
insightful, as it contains a fairly extensive analysis of coworker rights. ${ }^{116}$ The EEOC acknowledges in the manual that an employer can establish undue hardship if a religious accommodation results in certain types of harm to other employees. ${ }^{117}$ Specifically, an employer is not required to provide an accommodation that would diminish efficiency in other jobs, infringe on coworkers' job preferences or other benefits, compromise safety, interfere with others' ability to perform their job duties, create a hostile work environment, or cause a disruption of work. ${ }^{118}$ Conspicuously absent from this list is employee morale. This is hardly unintentional; the EEOC has made clear its position that coworkers' feelings about an accommodation are largely irrelevant:

Although infringing on co-workers' ability to perform their duties or subjecting co-workers to a hostile work environment will generally constitute undue hardship, the general disgruntlement, resentment, or jealousy of coworkers will not. Undue hardship requires more than proof that some coworkers complained; a showing of undue hardship based on co-worker interests generally requires evidence that the accommodation would actually infringe on the rights of co-workers or cause disruption of work. ${ }^{119}$

In the EEOC's view, the only way an employer can prove undue hardship based on how an accommodation affects coworkers is to show the accommodation would interfere with their contractual rights or otherwise disrupt their work; the fact that an accommodation could harm coworker morale by causing disgruntlement, resentment, or jealousy is inconsequential, regardless of the severity of such feelings. The EEOC has not backed down from this position despite finding itself on the losing end of several cases in which courts have upheld morale-based hardships. ${ }^{120}$

The EEOC's disdain for morale-based hardships is also apparent in two question-and-answer sheets the agency has issued. In Questions and Answers About the Workplace Rights of Muslims, Arabs, South Asians, and Sikhs Under the Equal Employment Opportunity Laws, the EEOC presents two scenarios involving coworker morale. ${ }^{121}$ The first scenario involves a manager who

www.eeoc.gov/policy/docs/qanda_religion.html, archived at perma.cc/HC2Z-SKDG; 29 C.F.R. $\S 1605.2(\mathrm{e})(2)(2014)$.

116 See U.S. EQual EMP. Opportunity COMM'N, Complance MANuAL, supra note 115, $\S \S 12-I V-B-4,12-I V-C-6-a$.

${ }_{117}$ Id.

118 Id.

119 Id.

120 See, e.g., EEOC v. Firestone Fibers \& Textiles Co., 515 F.3d 307, 318 (4th Cir. 2008); EEOC v. Aldi, Inc., No. 06-01210, 2009 WL 3183077 at *14-15 (W.D. Pa. Sept. 30, 2009); EEOC v. JBS USA, LLC, No. 8:10CV318, 2013 WL 6621026 at*19 (D. Neb. Oct. 11, 2013).

${ }^{121}$ Questions and Answers About the Workplace Rights of Muslims, Arabs, South Asians, and Sikhs Under the Equal Employment Opportunity Laws, U.S. EQUAL EMP. 
declines to hire an applicant who wears a hijab because she is worried how others would feel about it. ${ }^{122}$ The EEOC explains that refusing to hire someone because customers or coworkers may feel uncomfortable with that person's religion is "just as illegal as refusing to hire that person because of religion ... in the first place." 223 In the second scenario, a supervisor asks a Sikh employee to remove his turban because it makes his coworkers feel uncomfortable. ${ }^{124}$ The EEOC responds that claiming coworkers might be upset or uncomfortable when they see the turban does not amount to undue hardship. ${ }^{125}$ In Questions and Answers: Religious Discrimination in the Workplace, the EEOC addresses the question, "What if co-workers complain about an employee being granted an accommodation?"126 As in the Compliance Manual, the EEOC disregards such complaints and contends undue hardship requires evidence that an accommodation would infringe on the rights of coworkers or cause disruption at work, not generalized complaints of disgruntlement, resentment, or jealousy. ${ }^{127}$

Although perhaps more notable for what they omit than for what they contain, the federal regulations also provide some insight into the EEOC's views on coworker rights. Despite identifying in the Compliance Manual several coworker rights that trump the right to a religious accommodation, ${ }^{128}$ the EEOC only acknowledges one such right, seniority, in the federal regulations. ${ }^{129}$ The regulations state that employers are not required to provide an accommodation that would deny other employees their job or shift preferences guaranteed by a bona fide seniority system. ${ }^{130}$ This is hardly a controversial proposition, as it is largely redundant of Hardison and Title VII's seniority-system provision. The EEOC's decision not to include other coworker rights in the federal regulations is somewhat curious. Perhaps it is because seniority is the only coworker right specifically referenced in Title VII and acknowledged by the Supreme Court. Updating the regulations may also not rank particularly high on the EEOC's list of priorities. ${ }^{131}$ A third possibility is that because courts are more likely to defer to the federal

OPPORTUNITY COMM'N (Mar. 21, 2005), www.eeoc.gov/facts/backlash-employee.html, archived at perma.cc/5ZLZ-Q2DW.

122 Id.

123 Id.

124 Id.

125 Id.

${ }^{126}$ Questions and Answers: Religious Discrimination in the Workplace, U.S. EQUAL EMP. OPPORTUNITY COMMISSION (last modified Jan. 31, 2011), www.eeoc.gov/policy/ docs/qanda_religion.html, archived at perma.cc. HC2Z-SKDG.

${ }^{127}$ Id.

128 U.S. EQUAl EMP. OpPORTUNiTy COMM'N, COMPLIANCE MANUAL, supra note 115, $\S 12-\mathrm{IV}-\mathrm{B}$.

12929 C.F.R. $\S 1605.2(\mathrm{e})(2)(2014)$.

130 Id.

131 The EEOC has not made any substantive changes to 29 C.F.R. $§ 1605.2$ since 1981. Compare 29 C.F.R. $\S 1605.2$ (1981), with 29 C.F.R. $§ 1605.2$ (2014). 
regulations than other agency materials, ${ }^{132}$ the EEOC deliberately interprets coworker rights as narrowly as possible to discourage courts and employers from placing excessive emphasis on how a religious accommodation would affect other employees.

In sum, although Title VII itself contains little regarding religious accommodations that interfere with coworker rights, both the Supreme Court and the EEOC have interpreted the statute in ways that seem to acknowledge coworkers are entitled to not be unfairly burdened by a religious accommodation. However, the parameters of coworker rights, particularly relating to morale, remain unclear, as courts have struggled to establish a consistent, unified approach to analyzing morale-based hardships.

\section{JUDICIAL ANALYSIS OF MORALE-BASED HARDSHIPS}

In the absence of clear guidance from the Supreme Court or Title VII itself, courts employ a variety of approaches to analyzing religious accommodations that harm employee morale. These approaches include analyzing the reasonableness of an employer's belief that an accommodation would hurt morale, the actual impact of an accommodation on morale, the objective offensiveness of an accommodation, and how an employer's business suffers due to low morale. This hodgepodge of approaches has produced an inconsistent and confusing case law that offers few guiding principles in navigating this sensitive and complex issue.

\section{A. Employer's Reasonable Belief}

One method of analyzing morale-based hardships is to focus on the reasonableness of the employer's belief that an accommodation will harm coworker morale. This approach is particularly well suited for cases where there is no direct evidence of hardship because the accommodation was never actually implemented. For example, in EEOC v. Firestone Fibers \& Textiles Co., Firestone refused to accommodate laboratory technician David Wise's request to not work from sundown Fridays to sundown Saturdays because the company feared more senior employees, who would be forced to fill in for Wise, would become disgruntled. ${ }^{133}$ In affirming summary judgment for Firestone, the Fourth Circuit focused on whether the company reasonably believed accommodating Wise would have more than a de minimis impact on coworker morale. ${ }^{134}$ The court agreed Firestone risked lowering morale by displaying favoritism if it were to exempt Wise from its attendance policy,

132 See Gulino v. N.Y. State Educ. Dep't, 460 F.3d 361, 383-84 (2d Cir. 2006) (explaining that courts are not bound by federal regulations promulgated by the EEOC, but nonetheless rely on them to promote consistency in the enforcement of antidiscrimination laws).

133 EEOC v. Firestone Fibers \& Textiles Co., 515 F.3d 307, 317-19 (4th Cir. 2008).

${ }^{134} I d$. at 317 . 
even though several of Wise's coworkers indicated they did not have a problem covering his absences. ${ }^{135}$ The court determined it was reasonable for Firestone to be concerned such feelings would be short lived, as the accommodation could carry with it a "sting of unfairness" that might leave more senior employees bitter about being forced to work during valuable personal or family time. ${ }^{136}$ The court observed that because feelings of inequality can cause "real problems" in the workplace, employers can consider the rights and perceptions of fairness of other employees in determining whether to provide a religious accommodation. ${ }^{137}$ The court further proclaimed: "[E]venhandedness and fairness are of paramount importance to the functioning of any workplace. Co-workers have their rights, too."138

The reasonableness of the employer's belief that an accommodation would hurt employee morale was again the focus of analysis in Aron v. Quest Diagnostics Inc. ${ }^{139}$ Stuart Aron, an Orthodox Jew, brought suit against Quest for denying him a phlebotomist position because his religious beliefs prevented him from working Saturdays. ${ }^{140}$ Quest had a longstanding policy requiring all phlebotomists to work at least two Saturdays per month. ${ }^{141}$ The company devised this policy, in part, to avoid employee-morale issues it believed could arise if some phlebotomists did not work their fair share of Saturdays. ${ }^{142}$ Quest consistently enforced this policy despite losing a number of otherwise qualified candidates who were unable to meet the Saturday work requirement. ${ }^{143}$ The district court granted summary judgment to Quest, concluding it was reasonable for the company to believe granting Aron an exemption from its Saturday work policy would hurt coworker morale. ${ }^{144}$ Because Quest consistently enforced this policy, it was reasonable for Quest to be concerned that making an exception for Aron when it had refused to do so for others might lead to perceptions of unequal treatment that could hurt morale. ${ }^{145}$ Significantly, the court rejected Aron's argument that morale concerns alone cannot constitute undue hardship, reasoning that "Hardison establishes that the effect on other employees of an accommodation is a practical consideration in determining reasonableness."146 The court likewise rejected Aron's contention that because Quest never accommodated him, the

${ }^{135}$ Id. at 318 .

${ }^{136} I d$.

${ }^{137}$ Id.

${ }^{138}$ Id. at 319 .

139 Aron v. Quest Diagnostics Inc., No. Civ.A.03-2581 JSH, 2005 WL 1541060, at *6 (D.N.J. June 30, 2005).

${ }^{140} I d$. at $* 1-2$.

${ }^{141} I d$. at $* 2$.

142 Id.

${ }_{143}$ Id

${ }^{144} I d$. at *7.

145 Aron, 2005 WL 1541060, at *7.

${ }^{146}$ Id 
company's concern that exempting him from Saturday work would hurt morale was merely hypothetical. ${ }^{147}$ In the court's view, Quest offered reasons for not breaking its policy based on actual imposition on coworkers or disruption of work, which motivated the company to consistently enforce its policy, even in the face of losing employees. ${ }^{148}$

Not all courts that use the "reasonable belief" test show the level of deference to employers on display in Firestone and Quest Diagnostics. In Lambert v. Condor Manufacturing, Inc., machine operator Victor Lambert was fired for refusing to work in an area where other employees displayed photographs of nude women. ${ }^{149}$ Lambert complained to management that the photos violated his religious beliefs and requested their removal as a religious accommodation. ${ }^{150}$ Condor denied Lambert's request because it feared other employees would become upset if forced to take down the pictures. ${ }^{151}$ The district court expressed doubt that Condor's concern for employee morale was reasonable in this instance, as there was conflicting evidence over how important the pictures were to employee morale and how much of a detrimental effect their removal would have on other employees. ${ }^{152}$ In denying Condor's motion for summary judgment, the court signaled its skepticism of morale-based hardships, noting that "proof of co-workers' unhappiness with a particular accommodation is not enough to cause a hardship." 153

Similarly, in Burns v. Southern Pacific Transportation Co., the Ninth Circuit determined the company and union's belief that exempting an employee from paying union dues would hurt employee morale was unreasonable. ${ }^{154}$ Duane Burns, a Seventh-day Adventist, withdrew from the union after realizing his affiliation with the union and payment of dues conflicted with the teachings of his church. ${ }^{155}$ Burns offered to pay the

\footnotetext{
${ }^{147}$ Id. at $* 7-8$.

148 Id. at $* 8$.

${ }^{149}$ Lambert v. Condor Mfg., Inc., 768 F. Supp. 600, 601 (E.D. Mich. 1991).

${ }^{150} \mathrm{Id}$. at $602-03$.

151 Id. at 604 .

152 Id.

${ }^{153} I d$. (citation omitted) (internal quotation marks omitted). Condor also argued that aside from harming coworker morale, removing the photos would violate other employees' free speech rights. Id. Although Condor did not expressly argue that violating constitutional rights can lower employee morale, such an argument can be inferred. The court dismissed this argument based on Condor's status as a private employer. Id. However, as Professor Eugene Volokh points out, First Amendment concerns persist whenever religious accommodation law is used to force an employer to suppress speech. Eugene Volokh, Freedom of Speech, Religious Harassment Law, and Religious Accommodation Law, 33 LoY. U. CHI. L.J. 57, 65 (2001). Whereas private employers are free to restrict employee speech on their own without running afoul of the First Amendment, it is a much more serious matter when the government, acting through the court system, forces employers to suppress their employees' speech. Id.

${ }^{154}$ Burns v. S. Pac. Transp. Co., 589 F.2d 403, 406-07 (9th Cir. 1978).

${ }^{155} \mathrm{Id}$. at 405 .
} 
equivalent of union dues to a designated charity as an accommodation to his religious beliefs. ${ }^{156}$ The company and the union waived the requirement of union membership but refused to consider any accommodation that would involve Burns not paying union dues because they believed such an arrangement could result in serious dissension among other workers and therefore inefficiency of operation. ${ }^{157}$ In the subsequent lawsuit, the company and the union claimed undue hardship based on their belief that "free rider" problems could harm employee morale. ${ }^{158}$ The Ninth Circuit rejected their belief as unreasonable, noting the defendants' witnesses made no effort to "relate a general sentiment against free riders either to Burns or to a person who, like Burns, made payments equivalent to union dues to a charitable organization." 159 The mere possibility of employee dissatisfaction was too hypothetical in the court's view, as undue hardship requires "more than proof of some fellow-worker's grumbling or unhappiness with a particular accommodation to a religious belief." 160

\section{B. Actual Impact}

In some cases, courts analyze morale-based hardships by examining the accommodation's actual impact on employee morale. This approach is most common in cases where an employer implements an accommodation and thereafter claims hardship. In EEOC v. JBS USA, LLC, the EEOC alleged JBS engaged in a pattern and practice of discrimination by not allowing Somali Muslim meatpackers to take unscheduled breaks to pray and by failing to move their meal break during Ramadan to a time that coincided with the employees' sunset prayers. ${ }^{161}$ The court reasoned that "almost any religious accommodation will inevitably cause some differences in treatment among employees," but accommodations that cause a "'real' and 'actual' imposition on coworkers" are not required under Title VII. ${ }^{162}$ The court concluded that allowing employees to take unscheduled prayer breaks would impose greater than de minimis burden on coworkers who would have to fill in for the employees leaving the line. ${ }^{163}$ Not only would the substitutes not be performing their own jobs while covering for the absent employees, but they would also have to work harder and under more rigorous and potentially dangerous conditions. ${ }^{164}$ According to the court, this could negatively impact

${ }^{156} \mathrm{Id}$

${ }^{157}$ Id. at $405-06$.

$158 \mathrm{Id}$. at 406 .

159 Id.

160 Burns, 589 F.2d at 407.

${ }^{161}$ EEOC v. JBS USA, LLC, No. 8:10CV318, 2013 WL 6621026, at*4, *14 (D. Neb. Oct. 11, 2013).

${ }^{162} I d$. at *17 (quoting Harrell v. Donahue, 638 F.3d 975, 980 (8th Cir. 2011)).

163 Id. at $* 19$.

${ }^{164}$ Id. 
morale because coworkers would likely conclude they were forced to work harder and faster to cover for the Muslims taking extra breaks. ${ }^{165}$ As for moving the meal break, the court determined this, too, would impose undue hardship on coworkers because the locker rooms, restrooms, and cafeteria facilities were not large enough to accommodate such a large influx of employees. ${ }^{166}$ When the company tried in the past to adjust break times to accommodate the Muslim employees, other workers were upset because their work periods between breaks were uneven. ${ }^{167}$ Non-Muslim employees had even walked off the job because they were angry their work day was being shortened, meaning they would receive less pay. ${ }^{168}$ Accordingly, the court determined JBS was not required to implement either accommodation based, in part, on resistance from non-Muslim employees whose morale had been, and would continue to be, negatively impacted if JBS implemented the accommodations. ${ }^{169}$

An accommodation's impact on coworker morale was likewise the Eighth Circuit's focus in Wilson v. U.S. West Communications. ${ }^{170}$ Christine Wilson, a Roman Catholic, vowed she would wear a button depicting a color photograph of a fetus until there was an end to abortion or until she could no longer continue fighting. ${ }^{171}$ Several of Wilson's coworkers took offense to the button, and some of them even threatened to walk off their jobs. ${ }^{172}$ Wilson's coworkers testified they found the button offensive and disturbing for personal reasons unrelated to any stance on abortion or religion, including infertility problems, miscarriage, and death of a premature infant. ${ }^{173}$ U.S. West argued the negative impact of Wilson's button had resulted in a forty-percent decrease in productivity among her coworkers. ${ }^{174}$ Moreover, when U.S. West temporarily allowed Wilson to return to work wearing the button, some workers refused to attend meetings with her present, complained to management that the button made them feel uneasy, and two employees filed grievances accusing management of harassment for not resolving the issue to their satisfaction. ${ }^{175}$ In affirming summary judgment for U.S. West, the Ninth Circuit concluded there was "no doubt" that allowing Wilson to wear the button uncovered would have resulted in undue hardship. ${ }^{176}$ Although the

$165 \mathrm{Id}$.

$166 I d$. at $* 20$.

167 JBS USA, 2013 WL 6621026, at *20. The court explained that breaks at uniform periods of time were especially important to employees because work at the plant is heavy, tiring, and takes place in very cold conditions. $I d$.

168 Id.

$169 \mathrm{Id}$.

170 See Wilson v. U.S. W. Commc'ns, 58 F.3d 1337 (8th Cir. 1995).

${ }^{171}$ Id. at 1339.

172 Id.

173 Id.

${ }^{174}$ Id.

175 Id.

176 Wilson, 58 F.3d at 1342 n.3. 
court did not elaborate on how it reached this conclusion, its detailed recitation of how the button impacted other employees suggests this was a major factor in the court's determination.

By contrast, in Brown v. Polk County, Iowa, the Eighth Circuit ruled that an employee's religious expression had not sufficiently impacted coworker morale to justify the county's refusal to provide a religious accommodation. ${ }^{177}$ Larry Brown, a born-again Christian and former department head, alleged his former employer failed to accommodate his religious expression, which included holding prayer meetings and occasionally affirming his Christianity and referencing Bible passages in front of some of his employees. ${ }^{178}$ The county claimed accommodating Brown would cause undue hardship by eventually polarizing born-again Christian employees and other employees, and a concomitant perception that Brown would favor those who shared his beliefs in making personnel decisions. ${ }^{179}$ The county administrator testified that some employees expressed concerns about the possible effect of Brown's religious beliefs on his personnel decisions, and that he believed the atmosphere of religion that pervaded Brown's department hurt employee morale. ${ }^{180}$ A supervisor in Brown's department also testified that she heard some employees were concerned Brown's religious beliefs would affect his personnel decisions. ${ }^{181}$ The court rejected this evidence as too speculative because there was no proof Brown's religious expression had actually impacted other workers or that employee concerns were reasonable or legitimate. ${ }^{182}$ The county administrator conceded he had not received any direct complaints about Brown's behavior or personally witnessed problems between Christian and non-Christian employees. ${ }^{183}$ Also, three employees testified that any morale problems in Brown's department stemmed from disagreement about how the work should be done rather than religious issues. ${ }^{184}$ Thus, the alleged hardship was insufficiently real and too hypothetical because, unlike in Wilson, the county failed to prove Brown's religious expression actually harmed coworker morale. ${ }^{185}$

In EEOC v. Aldi, Inc., the district court instructed the jury to consider the effect granting cashier Kimberly Bloom Sundays off would have had on coworker morale. ${ }^{186}$ Aldi introduced evidence at trial that if it were to exempt Bloom from Sunday shifts, it would suffer an undue hardship in the form of

177 Brown v. Polk Cnty., 61 F.3d 650, 655-57 (8th Cir. 1995).

${ }^{178}$ Id. at $652-53$.

${ }^{179} \mathrm{Id}$. at 656 .

$180 \mathrm{Id}$

${ }^{181} \mathrm{Id}$. at $656-57$.

182 Id. at 657.

183 Brown, 61 F.3d at 656.

184 Id. at 657 .

$185 \mathrm{Id}$.

${ }^{186}$ EEOC v. Aldi, Inc., No. 06-01210, 2009 WL 3183077, at*12 (W.D. Pa. Sept. 30, 2009). 
lowered employee morale, employees quitting in protest, and the cost of training new employees. ${ }^{187}$ Based on this evidence, the court advised the jury:

An accommodation does not result in an undue hardship just because other employees are unhappy about it. An employer does not meet its burden of proving undue hardship merely by showing the accommodation is viewed as bothersome or unfair by other employees. An accommodation can result in undue hardship if it would impose unequal treatment on other employees, negatively affect employee morale, diminish efficiency, cause other employees to work a disproportionate workload, and divert them from their regular work. ${ }^{188}$

After the jury returned a verdict in favor of Aldi, the EEOC moved for a new trial, arguing in part that the court's instruction was erroneous because it amounted to a "coworker veto" by allowing the jury to conclude that coworker unhappiness could constitute undue hardship. ${ }^{189}$ Although the court agreed that "an adverse effect on the interests or happiness of coworkers is not enough to constitute an undue hardship," it concluded the instruction was not erroneous because the first portion made clear an employer cannot deny an accommodation because other employees would be unhappy or perceive it as bothersome or unfair, and the second part allowed the jury only to consider morale together with other adverse effects. ${ }^{190}$ The court concluded that together these portions of the jury instruction "directed the jury that they could not find undue hardship if the accommodation was only considered to be bothersome or unfair by other employees, but they could find undue hardship if the accommodation had a more serious negative impact on employee morale." 191 The court did not expound on what it considered a "more serious negative impact." Thus, while the court took the position coworker unhappiness or perceptions of unfairness do not constitute undue hardship, it left open the question of how seriously an accommodation must impact coworker morale before an employer can rightfully withhold an accommodation.

In Opuku-Boateng v. California, the Ninth Circuit rejected the California Department of Food and Agriculture's claim of undue hardship because there was no proof the accommodation would adversely impact other workers. ${ }^{192}$ Kwasi Opuku-Boateng secured a job as a plant inspector with the department at a border-inspection station. ${ }^{193}$ Upon hire, Opuku-Boateng informed his supervisor that his religion prohibited him from working sundown Fridays to sundown Saturdays. ${ }^{194}$ Because all fifteen inspectors at the station were

187 Id.

188 Id.

189 Id. at $* 13$.

${ }^{190}$ Id. at $* 13-14$ (citations omitted).

${ }^{191} I d$. at *14.

192 Opuku-Boateng v. California, 95 F.3d 1461, 1469-70 (9th Cir. 1996).

${ }^{193}$ Id. at $1464-65$.

${ }^{194} I d$. at 1465. 
required to work an equal number of undesirable weekend, holiday, and night shifts, Opuku-Boateng offered either to work additional undesirable nonSabbath shifts or to trade shifts with other employees. ${ }^{195}$ The department rejected Opuku-Boateng's proposals after a survey of other inspectors indicated only one or two employees would be willing to swap shifts with Opuku-Boateng on rare occasions, and none were willing to do so permanently. ${ }^{196}$ The department rescinded the job offer out of concern accommodating Opuku-Boateng would damage coworker morale. ${ }^{197}$

The Ninth Circuit acknowledged that in some cases an employer may be able to establish undue hardship based on how an accommodation impacts other workers, but questioned whether harm to employee morale warrants the same consideration as more established rights such as seniority and safety. ${ }^{198}$ The court rejected the department's claim that accommodating OpukuBoateng would result in substantial morale problems, reasoning that because all employees were required to work an equal number of undesirable weekend, holiday, and night shifts, Opuku-Boateng would not have received preferential treatment by being assigned a holiday, Sunday, or night shift for every shift he missed to observe his Sabbath. ${ }^{199}$ The court concluded this accommodation would not adversely affect morale because the inspectors would still work the same number of undesirable shifts; the only difference was they would work more undesirable weekend shifts and fewer undesirable holiday or night shifts. 200 This argument assumes inspectors considered weekend, holiday, and night shifts equally undesirable. However, the evidence showed weekends were the least desirable shifts because the workload was heaviest during the weekend period and weekend shifts were the most difficult to adequately staff. 201

The Ninth Circuit likewise rejected the trial court's finding that accommodating Opuku-Boateng would have compromised the department's ability to accommodate the scheduling needs of other employees, leading to significant morale problems. ${ }^{202}$ Because the court previously had determined accommodating Opuku-Boateng would not result in preferential treatment

${ }^{195}$ Id.

196 Id. at 1466.

197 See id.

198 Opuku-Boateng, 95 F.3d at 1468 n.12. The court noted that Hardison and Bhatia v. Chevron U.S.A., Inc., 734 F.2d 1382 (9th Cir. 1984) (a Ninth Circuit case denying a religious accommodation that would have compromised workplace safety) involved accommodations that would have resulted in "a significant discriminatory impact" on other employees. Opuku-Boateng, 95 F.3d at 1468 n.12. The court considered coworker morale distinct from seniority rights and safety, observing "[i]t is less clear what type of impact on coworkers, apart from a significant discriminatory impact, constitutes undue hardship." Id. at 1468.

199 Opuku-Boateng, 95 F.3d at 1470.

200 Id.

${ }^{201} \mathrm{Id}$. at 1466.

${ }^{202} I d$. at 1473. 
because everyone would still work the same number of undesirable shifts, the likely impact on employee morale was too hypothetical to establish undue hardship. ${ }^{203}$ In the absence of preferential treatment, any complaints from coworkers would amount to mere grumbling rather than significant morale problems. ${ }^{204}$ In the court's view, "[e]ven proof that employees would grumble about a particular accommodation is not enough to establish undue hardship." 205

In Shatkin v. University of Texas at Arlington, a Texas district court relied on the actual-impact test to reject the employer's claim of undue hardship. ${ }^{206}$ The university fired administrative assistants Evelyne Shatkin and Linda Shifflett for engaging in a prayer ceremony over coworker Evelyn Knight's cubicle in an effort to end their personal difficulties with Knight. ${ }^{207}$ They selected a time to pray when they knew Knight would be out of the office. ${ }^{208}$ According to her religious tradition, Shatkin rubbed olive oil on the doorway to Knight's cubicle and then prayed for Knight to find peace and "deep joy." 209 Shatkin then started chanting in a loud and accelerated manner the phrase, "I command you demons to leave [Knight], you vicious evil dogs get the hell out of here in the name of Jesus, get the hell out of [Knight]."210 During the university's subsequent investigation of the matter, Shatkin and Shifflett requested a religious accommodation to engage in brief, nondisruptive prayer during non-work time. ${ }^{211}$ The university denied this request and fired the plaintiffs upon determining their behavior violated the university's harassment policy. ${ }^{212}$ The university moved for summary judgment, claiming it could not possibly accommodate the plaintiffs "in the interest of 'preventing the harassment of employees and the escalation of tensions in the office."'213 The court denied the university's motion, in part because Knight did not learn about the prayer session until two months after the fact. ${ }^{214}$ The court reasoned, "[c]an prayer for someone constitute harassment when the alleged object of the prayer is unaware of it? This Court suspects not." 215 Accordingly, despite the plaintiffs' fairly aggressive and

${ }^{203}$ Id. at $1473-74$.

204 Id.

205 Id. at 1473 (quoting Anderson v. Gen. Dynamics Convair Aerospace Div., 589 F.2d 397, 402 (9th Cir. 1978), cert. denied, Int'l Ass'n of Machinists \& Aerospace Workers AFL-CIO v. Anderson, 442 U.S. 921 (1979)).

${ }^{206}$ Shatkin v. Univ. Tex. Arlington, No. 4:06-CV-882-Y, 2010 WL 2730585 (N.D. Tex. July 9, 2010).

207 Id. at $* 1-3$.

208 Id. at $* 1$.

${ }^{209} \mathrm{Id}$.

$210 I d$. (alteration in original).

211 Id. at $* 2$.

212 Shatkin, 2010 WL 2730585, at *2.

213 Id. at $* 7$.

214 Id. at $* 6,8$.

215 Id. at $* 6$. 
intimidating actions, the fact that such expression did not impact the targeted coworker until two months later precluded summary judgment.

\section{Objective Offensiveness}

Some courts analyze morale-based hardships by focusing on the objective offensiveness of a religious accommodation. This approach is most common in cases involving proselytization or other overt acts of religious expression. In Chalmers v. Tulon Co. of Richmond, the Fourth Circuit utilized this approach in affirming summary judgment for Tulon after it fired Charita Chalmers for sending letters to coworkers at their homes calling them to repent. ${ }^{216}$ Chalmers believed it was her responsibility as an evangelical Christian to share the gospel with others. ${ }^{217}$ When Chalmers perceived her supervisor had been dishonest with customers, she sent him a letter to his home address in which she stated: "[Y]ou are doing somethings [sic] in your life that God is not please [sic] with and He wants you to stop. All you have to do is go to God and ask for forgiveness before it's too late." 218 She further stated: "I wrote this letter at home so if you have a problem with it you can't relate it to work."219 While investigating this incident, Tulon discovered Chalmers sent a second letter, this time to her direct subordinate, Brenda Combs, who was suffering from an undiagnosed illness after giving birth out of wedlock. ${ }^{220}$ Chalmers stated in the letter: "One thing about God, He doesn't like when people commit adultery. You know what you did is wrong, so now you need to go to God and ask for forgiveness." 221 Both letter recipients were upset by the letters, although Combs acknowledged the letter did not offend her or damage her working relationship with Chalmers. ${ }^{222}$ Chalmers was ultimately fired for her religious expression and thereafter brought suit, alleging in part that her religious motive for writing the letters required Tulon to accommodate her conduct. $^{223}$ The Fourth Circuit made short work of Chalmers's religious accommodation claim. Rather than focus on how accommodating Chalmers's conduct would impact coworkers, the court emphasized the objective offensiveness of her religious expression. With almost no analysis, the court declared that Chalmers's conduct "is not the type that an employer can possibly accommodate," and that "Tulon was without power under any circumstance to accommodate Chalmers's need." 224 It is evident the court believed Chalmers's religious expression crossed a line and felt comfortable

${ }^{216}$ Chalmers v. Tulon Co., 101 F.3d 1012, 1012 (4th Cir. 1996).

217 Id. at 1014.

218 Id. at 1015 (alteration in original).

219 Id.

${ }^{220} \mathrm{Id}$. at 1016.

221 Id.

222 Chalmers, 101 F.3d at 1016.

${ }^{223} \mathrm{Id}$. at 1018-19.

${ }^{224}$ Id. at 1021. 
affirming summary judgment for Tulon on that basis alone and without further analysis.

Similarly, in Mitchell v. University Medical Center, Inc., Claudette Mitchell brought suit against her former employer alleging it failed to accommodate her need to proselytize other employees. ${ }^{225}$ Mitchell was a devout Christian who believed God directed her to certain biblical passages from which she was able to calculate the date of the end of the world or "the date of the Antichrist." 226 She shared her calculations and revelations with coworkers, several of whom complained to management that Mitchell's proselytizing made them feel uncomfortable. ${ }^{227}$ Some of Mitchell's coworkers told her directly that she was scaring them, and one even threatened to quit talking to her if she continued discussing her calculations. ${ }^{228}$ Management allowed Mitchell to continue her employment, but warned that if other employees complained about similar conversations they would have to revisit the issue. ${ }^{229}$ Mitchell subsequently resigned her employment and brought suit against the medical center for failing to accommodate her religious beliefs. ${ }^{230}$

The district court granted summary judgment to the medical center, concluding Mitchell could not be accommodated without undue hardship. Like in Chalmers, the court focused more on the nature of Mitchell's religious expression than the effect it had on other workers. Characterizing Mitchell's conversations as "offensive and troubling," the court concluded there was no way to accommodate Mitchell's religious beliefs without unduly burdening the medical center. ${ }^{231}$

In Peterson v. Hewlett-Packard Co., the Ninth Circuit crafted a balancing test to determine the objective offensiveness of an accommodation. ${ }^{232}$ Richard Peterson was upset by Hewlett-Packard's workplace diversity campaign, which he perceived as pro-homosexual. ${ }^{233}$ Peterson responded by posting three Bible verses on an overhead bin in his work cubicle, including the controversial passage from Leviticus: "If a man also lie with mankind . . . both of them have committed an abomination; they shall surely be put to death; their blood shall be put upon them." 234 Hewlett-Packard removed the scriptural passages out of concern they could be offensive to other employees

225 Mitchell v. Univ. Med. Ctr., Inc., No. 3:07CV-414-H, 2010 WL 3155842, at *1 (W.D. Ky. Aug. 9, 2010).

${ }^{226}$ Id. (internal quotation marks omitted).

227 Id. at $* 2$.

228 Id.

229 Id. at $* 3$.

230 Id.

231 Mitchell, 2010 WL 3155842, at *7.

232 Peterson v. Hewlett-Packard Co., 358 F.3d 599, 607 (9th Cir. 2004).

${ }^{233} I d$. at 601. As part of the campaign, Hewlett-Packard displayed in its workplace a series of five posters, each depicting a company employee above the caption "'Black,' 'Blonde,' 'Old,' 'Gay,' or 'Hispanic.'” Id.

${ }^{234}$ Id. at 601-02 (quoting Leviticus 20:13). 
and also violate the company's harassment policy. ${ }^{235}$ Peterson admitted to management that he intended the passages to be hurtful so his homosexual coworkers would feel motivated to repent and be saved. ${ }^{236}$ Hewlett-Packard discharged Peterson for reposting the verses after they were removed. ${ }^{237}$ In affirming summary judgment for Hewlett-Packard, the Ninth Circuit drew a distinction between religious expression that is "irritating or unwelcome" and religious expression that "demean[s] or degrade[s]." 238 The court cautioned that because "[c]omplete harmony in the workplace is not an objective of Title VII," an accommodation does not impose undue hardship merely because other employees find the religious conduct irritating or unwelcome. ${ }^{239}$ The court concluded that although an employer "must tolerate some degree of employee discomfort in the process of taking steps required by Title VII to correct the wrongs of discrimination, it need not accept the burdens that would result from allowing actions that demean or degrade, or are designed to demean or degrade, members of its workforce." 240 Thus, the Ninth Circuit measured the objective offensiveness of Peterson's religious expression by considering whether his actions were merely irritating and unwelcome or demeaning and degrading. In the court's view, an employer must permit the former, but can prohibit the latter.

\section{Harm to the Employer}

A final method of analyzing morale-based hardships is to focus on how harm to employee morale affects an employer's business. To date, only the Sixth Circuit has adopted this approach; it remains to be seen whether other circuits will follow suit. In Crider v. University of Tennessee, Knoxville, Kimberly Crider brought suit against her former employer for refusing to accommodate her request to not work weekends. ${ }^{241}$ Four days after beginning work as a programs-abroad coordinator, Crider informed her supervisor that her religion prevented her from performing work from sundown Fridays until sundown Saturdays. ${ }^{242}$ Crider's job responsibilities included monitoring an emergency cell phone on a rotating basis, including weekends. ${ }^{243}$ Crider's supervisor asked the other two coordinators whether they would be willing to assume responsibility for the phone every other weekend to accommodate Crider. ${ }^{244}$ Her coworkers refused because they would be unable to travel or

235 Id. at 602 .

236 Id.

237 Id.

238 Peterson, 358 F.3d at 607-08.

${ }^{239} \mathrm{Id}$. at 607.

${ }^{240}$ Id. at $607-08$.

${ }^{241}$ Crider v. Univ. Tenn., Knoxville, 492 F. App'x 609, 610-11 (6th Cir. 2012).

$242 \mathrm{Id}$. at 610 .

243 Id.

${ }^{244} I d$. at 611 . 
disengage from work. ${ }^{245}$ One of the coworkers threatened to quit if forced to cover Crider's weekend shifts. ${ }^{246}$ Rather than risk other employees quitting or feeling disgruntled, the university declined to accommodate Crider and instead terminated her employment. ${ }^{247}$

The Sixth Circuit rejected the university's argument that an employer can establish undue hardship based solely on how an accommodation affects coworkers. ${ }^{248}$ The court reasoned that Title VII requires an employer to show an accommodation would cause undue hardship on the conduct of its business - not coworkers. ${ }^{249}$ Thus, an accommodation's impact on coworkers is only relevant to the extent it affects an employer's business. The court expressed skepticism that coworker morale issues can cause undue hardship, noting that "objections and complaints of fellow employees, in and of themselves, do not constitute undue hardship in the conduct of an employer's business ...." 250 The court further reasoned that employee dissatisfaction or inconvenience alone does not create undue hardship, but rather "it is the effect such dissatisfaction has on the employer's ability to operate its business that may alleviate the duty to accommodate." 251 The court made clear the effect of coworker dissatisfaction on an employer's business must be substantial, noting: "“[I]t is conceivable that employee morale problems could become so acute that they would constitute undue hardship' and that such discontent can lead to "chaotic personnel problems." 252 In applying this standard, the court largely ignored the coworkers' concerns over having to work additional weekends and instead focused exclusively on one coworker's threat to quit her job if the university accommodated Crider. The court acknowledged the coworker quitting could potentially qualify as a "chaotic personnel problem," but because the university failed to prove the threat amounted to more than mere grumbling, a fact issue persisted as to whether the university would experience undue hardship. 253

The foregoing cases illustrate the struggle courts face in analyzing moralebased hardships. In the absence of clear guidance from the Supreme Court or the text of Title VII itself, courts have fashioned a variety of analytical approaches, each emphasizing different aspects of morale. Consequently, the resulting case law is fairly erratic and offers few guiding principles. Can an employer withhold an accommodation if it reasonably believes the accommodation would harm morale, or should it instead focus on an

245 Id.

246 Id. at 613 .

247 Crider, 492 F. App'x at 611.

$248 I d$. at 614 .

249 Id.

${ }^{250} I d$. at 613 (quoting Draper v. U.S. Pipe \& Foundry Co., 527 F.2d 515, 520 (6th Cir. 1975)).

$251 \mathrm{Id}$. at 614 .

252 Id. at 615 (quoting Draper, 527 F.2d at 521).

253 Id. 
accommodation's impact on other employees? Should an employer consider the objective offensiveness of an accommodation, or is it better to concentrate on how harm to morale would affect its business? The difficulty these questions present for legal practitioners is amplified for employers, many of whom are unsophisticated and lack the legal prowess necessary to make a fully-informed determination.

\section{Giving Morale Its Due}

The importance of employee morale is beyond question. At the individual level, morale affects an employee's mental and physical health, which in turn influences job performance, absenteeism, commitment, and advocacy. ${ }^{254}$ At the organizational level, high morale is positively correlated with, and in some cases drives, financial performance, workplace safety, employee retention, and a host of other outcomes. ${ }^{255}$ Despite being one of an organization's most important assets, courts are often skeptical of claims that a religious accommodation will harm coworker morale. This skepticism may stem from the fact that unlike more tangible business outcomes such as profitability, productivity, or safety, employee morale is a somewhat nebulous concept that cannot easily be operationalized or measured. Or perhaps some courts are uncomfortable with the notion coworkers should influence whether an employee receives a religious accommodation. Whatever the case may be, Hardison plainly establishes that an employer is not required to provide an accommodation that imposes any cost that is more than de minimis. 256 Because the law does not distinguish between types of cost, but only the amount of cost, courts have no basis for considering employee morale as less legitimate than any other type of hardship.

To ensure courts give employee morale the protection it deserves, three changes to judicial analysis are needed. First, courts should distinguish between valid and invalid reasons why an accommodation might threaten coworker morale. An accommodation can affect morale for different reasons. Drilling down and determining the true reason would make it easier for courts to determine when morale should trump an accommodation and when it should not. Second, courts should accept that an employer can establish undue hardship based on harm to employee morale alone, without requiring further proof of how lowered morale adversely affects the business. Third, courts should focus on the reasonable likelihood an accommodation will harm morale in deciding the issue of undue hardship. These recommendations could make it easier for employers to prove morale-based hardship in appropriate cases, give greater voice to innocent coworkers, and produce a more uniform case law that

254 See supra Part II.A.

255 See supra Part II.A.

256 Trans World Airlines, Inc. v. Hardison, 432 U.S. 63, 84 (1977). 
provides clear and practical guidance in determining the appropriate parameters of religious accommodations that threaten coworker morale.

\section{A. Distinguishing Valid from Invalid Harm to Morale}

The most important change courts can make to their analysis of religious accommodations that threaten coworker morale is to distinguish between valid and invalid harm to morale. Too often courts analyze morale in general terms without bothering to consider that an accommodation can harm morale for different reasons. Does an accommodation hurt morale because other employees disagree with the accommodation seeker's religious beliefs? Is it because other employees perceive the accommodation as inherently unfair? Or is morale diminished because an accommodation changes other workers' employment in ways that make their jobs less satisfying? ${ }^{257}$ Because Title VII's purpose is to eliminate discrimination in the workplace, ${ }^{258}$ harm to morale based on religious animus or perceptions of unfairness are invalid because they undermine the statute's aim. By contrast, harm to morale that stems from an accommodation's effect on other workers' employment is valid because it is based on changes in the terms and conditions of their own employment, which the Supreme Court has acknowledged is an appropriate consideration in balancing the equitable interests of Title VII plaintiffs and innocent third parties. ${ }^{259}$ When a court fails to draw this distinction, it runs the risk of either allowing invalid harm to morale to trump an employee's right to a religious accommodation or of upholding an accommodation that hurts morale for a valid, nondiscriminatory reason. Analyzing why an accommodation harms coworker morale will enable courts to avoid this problem.

\section{Harm to Morale Based on Religious Animus}

In some cases, an accommodation can hurt coworker morale because of the animus, negative stereotypes, or unfounded fears of coworkers. ${ }^{260}$ For example, a telemarketing company has a rule prohibiting employees from displaying non-work-related materials in their cubicles but nevertheless agrees to accommodate a Muslim employee by allowing him to keep a Quran at his desk. This upsets other workers who view the Quran as a symbolic threat to their own beliefs. They also suspect the Muslim employee is becoming more

257 See Key, supra note 66, at 1009-11. Professor Key argues that in context of disability discrimination, an accommodation can impact coworkers based on discriminatory animus, perceptions of unfairness, and the impact an accommodation has on other workers' employment. Id. There is no reason to believe the impact of a religious accommodation on coworkers would be any different.

258 See Griggs v. Duke Power Co., 401 U.S. 424, 431 (1971).

259 See supra Part III.B.

260 See Key, supra note 66, at 1009. 
radical and fear he may be planning some sort of terrorist attack. In this case, coworkers have become disgruntled not because they perceive the accommodation as unfair or because the accommodation directly affects their own employment, but because they disagree with or are suspicious of the Muslim employee's religious beliefs based on discriminatory animus or unfair stereotypes.

In this scenario, harm to coworker morale is no less real simply because it stems from discriminatory animus. But it is less valid. Congress's purpose in enacting Title VII was "the removal of artificial, arbitrary, and unnecessary barriers to employment when the barriers operate invidiously to discriminate on the basis of racial or other impermissible classification." 261 As Professor Lisa E. Key rightly points out, to permit harm to morale to be considered in determining an employer's accommodation obligation under such circumstances would be to condone these discriminatory attitudes implicitly. ${ }^{262}$ Moreover, this type of harm stems less from the accommodation itself than from the animus coworkers feel toward the accommodated employee's religious beliefs. In the case of the Muslim employee who displays the Quran at his desk, any resulting discomfort other employees experience is more likely to arise from their aversion to Islam than from the presence of the book. When the source of lowered morale is the accommodated employee's religious beliefs instead of the accommodation itself, it is not the accommodation that causes undue hardship but rather the discriminatory attitudes of other workers. Because the goal of Title VII is to eliminate such discrimination, animus-based harm to morale cannot be a legitimate reason to deny an accommodation, even though the resulting harm to other employees and the business as a whole could very well be more than de minimis. Excluding animus-based harm to morale as evidence of undue hardship is consistent with Title VII's goal of eradicating discrimination in the workplace.

\section{Harm to Morale Based on Coworkers' Perceptions of Unfairness}

A religious accommodation can also damage morale based on coworkers' perceptions that the accommodated employee is receiving unwarranted preferential treatment. ${ }^{263}$ Even if the accommodation has no direct impact on others' employment, it can nonetheless hurt morale because coworkers' expectational interests are disrupted by what they perceive as an employee being unfairly rewarded despite not meeting established criteria or in a way that is inconsistent with company policy. ${ }^{264}$ For instance, an employer permits an Orthodox Jewish employee to wear skirts to work as a religious accommodation even though everyone else must wear the company uniform

261 Griggs, 401 U.S. at 431.

262 Key, supra note 66, at 1037.

263 Id. at $1009-10$.

${ }^{264} I d$. 
consisting of a polo shirt and khaki pants. This outrages coworkers, not because they feel any hostility toward Judaism, nor because the accommodation affects their own employment, but because they believe it is unfair or unjust to exempt the employee from a company-wide policy simply because of her religious beliefs.

Harm to morale based on perceptions of unfairness is more difficult to dismiss than animus-based harm. This is because the harm is not caused by religious hostility or unfair stereotypes - the types of discriminatory beliefs Title VII seeks to eradicate-but because one employee is being treated differently from everyone else due to her religious beliefs - which, at least facially, also runs counter to Title VII's call for equality. In this sense, it is difficult to fault employees for feeling resentful when a coworker receives preferential treatment because of her religious beliefs, especially since the average American worker likely has little knowledge of an employer's religious accommodation obligations under the law. Regardless, Title VII mandates preferential treatment on the basis of religion in some situations despite other workers' perceptions that such treatment is unfair. ${ }^{265}$ An individual is never exempt from a law simply because she believes the law is unfair. Likewise, an employer cannot be excused from providing a religious accommodation based on other employees' perceptions of unfairness. Title VII does not guarantee equal treatment on the basis of religion, but instead imposes an affirmative obligation on employers to treat religious employees differently by accommodating certain religious beliefs. Because this is the law, employees should expect employers to make reasonable accommodations in accordance with Title VII. ${ }^{266}$ Although harm to morale based on perceptions of unfairness is understandable on some level, it cannot constitute a valid basis

265 Some courts attempt to downplay the inherent inequality of religious accommodations by drawing a distinction between accommodations that result in differential versus preferential treatment. See, e.g., Bruff v. N. Miss. Health Servs., Inc., 244 F.3d 495, 502 (5th Cir. 2001) (noting the plaintiff had confused differential treatment with preferential treatment); Opuku-Boateng v. California, 95 F.3d 1461, 1469-70 (9th Cir. 1996) ("We have not read Hardison so broadly as to proscribe all differences in treatment ... [but only] preferential treatment of employees."); Tooley v. Martin-Marietta Corp., 648 F.2d 1239, 1243 (9th Cir. 1981) (reasoning that disparate treatment of employees is not necessarily unreasonable because religious accommodation provisions only prohibit preferential treatment of employees). However, this seems a distinction without a difference. Virtually any accommodation can be considered preferential because it necessarily entails unequal treatment that benefits the accommodated employee. See Trans World Airlines, Inc. v. Hardison, 432 U.S. 63, 88 (1977) (Marshall, J., dissenting) (explaining an accommodation "will always result in a privilege being 'allocated according to religious beliefs,' ... unless the employer gratuitously decides to repeal the rule in toto"); EEOC v. JBS USA, LLC, No. 8:10CV318, 2013 WL 6621026, at*17 (D. Neb. Oct. 11,2013 ) (acknowledging that "almost any religious accommodation will inevitably cause some differences in treatment among employees").

266 See Key, supra note 66, at 1037. 
for denying a religious accommodation because it would undermine the very purpose of antidiscrimination law.

\section{Harm to Morale Based on an Accommodation's Impact on Other Workers' Employment}

Perhaps the most common way an accommodation harms morale is by adversely affecting the terms and conditions of others' employment. ${ }^{267}$ This can occur when employees are forced to work undesirable or additional shifts, perform extra job duties, or tolerate proselytizing or other overt religious expression as an accommodation for a religious employee. As the Firestone court pointed out, such accommodations can carry with them a "sting of unfairness" that can lead to substantial problems in the workplace. ${ }^{268}$ Not only does the accommodated employee appear to receive preferential treatment, but coworkers either are denied a reward despite meeting established criteria (e.g., the ability to select a preferred shift based on seniority) or are punished in spite of compliance with established policies (e.g., having to take on additional job duties despite satisfactory performance in their own jobs). ${ }^{269}$ As with harm to morale based on the perception of unfairness, when an accommodation changes coworkers' employment, their expectational interests are disrupted, leading to a perception of unfairness or injustice that diminishes morale. ${ }^{270}$ However, this perception is based less on how an accommodation favors one employee than how it disadvantages others. This is a subtle yet important distinction. Title VII requires preferential treatment of religious employees in certain cases, but protects employers from incurring undue hardship in doing so. If coworkers are upset solely because an accommodated employee receives preferential treatment, the harm to morale is invalid because Title VII in fact requires some preferential treatment. But if the harm to morale stems from how an accommodation affects other workers' employment, such harm is valid because Title VII does not require coworkers to bear more than a de minimis burden. ${ }^{271}$

When morale is lowered due to religious animus or a misunderstanding of what accommodation law requires, such harm cannot constitute undue hardship because the coworkers themselves are the cause of the harm, whether through their biases or ignorance of the law. By contrast, harm to morale caused by an accommodation's impact on other employees' working conditions has nothing to do with animus or lack of understanding but instead results from the burden coworkers must bear because of the accommodation. In such cases, it is crucial to assess the impact an accommodation has on

${ }^{267}$ Id. at $1010-11$.

${ }^{268}$ EEOC v. Firestone Fibers \& Textiles Co., 515 F.3d 307, 318 (4th Cir. 2008).

${ }^{269} \mathrm{Key}$, supra note 66 , at 1011.

270 Id.

${ }^{271}$ See, e.g., Harrell v. Donahue, 638 F.3d 975, 980 (8th Cir. 2011) (undue hardship can be based on more than de minimis harm to the business or to coworkers). 
coworker morale to protect the rights of innocent third parties. Just as employers have the right to expect certain levels of profitability and productivity, employees are entitled to perform their jobs free of undue interference from other workers. While of course this right is not absolute, Hardison makes clear that religious accommodations that impose more than de minimis cost cannot be required under Title VII. ${ }^{272}$ Accordingly, when an accommodation hurts morale by negatively impacting the terms and conditions of coworkers' employment, it is imperative that courts recognize such harm to morale as a valid basis for proving undue hardship.

By taking the time to evaluate the reason an accommodation is harmful to employee morale, courts would be much better positioned to differentiate between cases where morale is a legitimate basis for establishing undue hardship from those cases where it is not. This could help alleviate concern that employers will use morale, whether intentionally or unintentionally, to perpetuate religious discrimination by allowing coworkers with religious biases or who are ignorant of the law to improperly influence whether an employee receives a religious accommodation.

\section{B. Proving Undue Hardship Through Harm to Morale Alone}

Judicial analysis of morale-based hardships could also be improved by allowing employers to prove undue hardship based on harm to coworker morale alone, rather than requiring additional proof of how lowered morale impacts an employer's business. Title VII excuses an employer from providing a religious accommodation only if the accommodation would cause "undue hardship on the conduct of the employer's business." 273 Whether this means an employer can prove undue hardship based on harm to coworkers alone is somewhat of an open question. A literal reading of the statutory text might suggest an employer can only prove undue hardship based on how an accommodation impacts the business itself. Yet most courts read the text more broadly as meaning an employer can prove undue hardship based on either harm to the business or to other employees. ${ }^{274}$ Although the Supreme Court has never addressed this issue, Hardison may have inadvertently contributed to the confusion. The Hardison court's analysis of undue hardship includes a

272 Trans World Airlines, Inc. v. Hardison, 432 U.S. 63, 84 (1977).

27342 U.S.C. $\S 2000 \mathrm{e}(\mathrm{j})(2012)$.

274 See, e.g., Harrell, 638 F.3d at 980 (undue hardship can be based on more than de minimis harm to the business or to coworkers); EEOC v. Firestone Fibers \& Textiles Co., 515 F.3d 307, 317 (5th Cir. 2008) (Title VII does not require employers to violate bargaining agreement or impose more than de minimis impact on coworkers.); Noesen v. Med. Staffing Network, Inc., 232 F. App'x 581, 584 (7th Cir. 2007) (“Undue hardship exists when a religious accommodation would cause more than minimal hardship to the employer or other employees."); Endres v. Ind. State Police, 349 F.3d 922, 925 (7th Cir. 2003) (interpreting Hardison as holding Title VII "does not require an accommodation that would cause more than minimal hardship to the employer or other employees"). 
discussion of how the various proposed accommodations would harm the company and coworkers. ${ }^{275}$ The Court gives no indication it views these harms as distinct; instead, it seems to use the harms almost interchangeably to support its finding of undue hardship. ${ }^{276}$ Consequently, Hardison both supports and undermines the notion an employer can prove undue hardship based on harm to coworkers alone. If an employer could only establish hardship based on an accommodation's impact on the business, why did the Court go to such great lengths in examining how the accommodations would affect other employees? But if an employer could establish undue hardship based on coworker harm alone, why did the Court also find it necessary to analyze how the accommodations would have impacted the business?

Even though most courts today read Hardison as meaning an employer can establish undue hardship based on either harm to its business or harm to other employees, Crider is a troubling departure from this practice. In concluding coworker harm alone is insufficient to prove undue hardship, the Sixth Circuit construed Title VII as narrowly as possible by emphasizing that the hardship at issue in Hardison had less to do with other employees than the fact the accommodation would have required the employer to breach the collective bargaining agreement. ${ }^{277}$ Although it is still too soon to determine whether other courts will adopt the reasoning of the Crider court, the case presents some concern that other circuits may follow suit in requiring employers to prove hardship beyond the accommodation's impact on other employees.

There are at least two reasons courts should recognize harm to coworkers as undue hardship. First, the link between employee morale and organizational performance is so well-established that it cannot be subject to reasonable dispute. ${ }^{278}$ As such, courts can and should take judicial notice of the fact that lowered employee morale constitutes a serious cost to an employer's business. ${ }^{279}$ Importantly, judicial notice would not relieve an employer of its obligation to show an accommodation's impact on coworker morale would be more than de minimis. If an employer wanted to rely on evidence of how lowered morale hurt its business, it would certainly have that option. ${ }^{280}$ But for the vast majority of employers without such data, judicial notice would allow them to avoid having to conduct expensive and time-consuming analyses of

275 Hardison, 432 U.S. at 78-84.

276 Id.

${ }^{277}$ Crider v. Univ. Tenn., Knoxville, 492 F. App’x 609, 614-15 (6th Cir. 2012).

278 See supra Part II.A.

${ }^{279}$ See FED. R. EVID. 201 (a court may take judicial notice of a fact that is "not subject to reasonable dispute" because either it is generally known within the court's territorial jurisdiction or it can be determined from sources whose accuracy cannot reasonably be questioned).

${ }^{280}$ See, e.g., Wilson v. U.S. W. Commc'ns, 58 F.3d 1337, 1339 (8th Cir. 1995) (employer presented evidence that accommodating the plaintiff by allowing her to wear a button depicting a fetus resulted in a forty percent decrease in worker productivity). 
the adverse effects of lowered morale on business operations. Moreover, because such analyses generally require an employer to implement an accommodation and wait to suffer some harm, judicial notice has the added benefit of enabling employers to prove hardship based on the likelihood, rather than the actuality, of harm. ${ }^{281}$ Given how low the Supreme Court set the evidentiary threshold for establishing undue hardship, allowing an employer to meet its burden based on harm to coworkers alone is wholly consistent with the high court's narrow construal of an employer's duty to provide a religious accommodation.

A second reason courts should recognize undue hardship based on harm to coworkers alone is because employees are an integral part of the organizations they work for. ${ }^{282}$ Therefore, harm to employees and harm to a business are essentially one in the same. Conceptualizing employees as part of an organization is hardly a controversial proposition. Under the doctrine of respondeat superior, an employer can be held liable for an employee's wrongful acts committed within the scope of employment precisely because the employee and the company are considered one in the same. ${ }^{283}$ In this sense, harm to employees is no different than harm to any other business asset, such as machinery, trade secrets, or reputation. It would be redundant to require an employer to prove how lowered morale hurts its business because lowered morale in and of itself constitutes a business harm.

\section{Proving Undue Hardship Based on Reasonable Likelihood of Harm}

Judicial analysis of morale-based hardships could also be improved if courts adopt a "reasonable likelihood" standard in evaluating an accommodation's impact on coworker morale. There is widespread disagreement among the courts as to the degree of certainty with which an

${ }^{281}$ A number of courts have concluded an employer can establish undue hardship based on the threat of harm rather than proof of actual harm. See, e.g., Weber v. Roadway Express, Inc., 199 F.3d 270, 275 (5th Cir. 2000) (citing Beadle v. City of Tampa, 42 F.3d 633 (11th Cir. 1995)) (an employer is not required to "wait until it felt the effects" of the proposed accommodation before determining its reasonableness); Abdelwahab v. Jackson State Univ., No. 3:09CV41TSL-JCS, 2010 WL 384416, at *2 (S.D. Miss. Jan. 27, 2010) (citing Weber, 199 F.3d at 274) ("[T]he mere possibility of an adverse impact on coworkers . . . is sufficient to constitute an undue hardship.") (alteration in original); Aron v. Quest Diagnostics Inc., No. Civ.A.03-2581 JSH, 2005 WL 1541060, at*8 (D.N.J. June 30 , 2005) (employer not required to implement accommodation before reasonably concluding morale would suffer); EEOC v. DalFort Aerospace, L.P., No. 3:00-CV-0666P, 2002 WL 255486, at*6 (N.D. Tex. Feb. 19, 2002) (same).

282 See Griffin Toronjo Pivateau, Preserving Human Capital: Using the Noncompete Agreement to Achieve Competitive Advantage, 4 J. BUS. ENTREPRENEURSHIP \& L. 319, 320 (2011) (organizations are increasingly adopting a human capital theory that conceptualizes employees as one of the most valuable assets of an organization).

283 See W. Page Keeton et Al., Prosser and Keeton on the Law of Torts 499501 (5th ed. 1984) (describing justifications for respondeat superior liability). 
employer must prove an accommodation will result in undue hardship. The Eighth and Ninth Circuits apply the most stringent standard, requiring an employer to prove the accommodation will result in actual imposition on coworkers or disruption of the work routine. ${ }^{284}$ By contrast, the Fifth and Sixth Circuits apply the least demanding standard, requiring an employer only to show the "mere possibility" of adverse impact. ${ }^{285}$ Other circuits take more measured approaches. In the First and Tenth Circuits, for example, an employer can prove undue hardship without actually implementing an accommodation by "examining the specific hardships imposed by specific accommodation proposals." 286 Similarly, the Fourth Circuit allows an employer to prove undue hardship if the employer reasonably believes an accommodation would impose more than a de minimis impact on coworkers. ${ }^{287}$ Not surprisingly, this variation of standards is a major contributor to the inconsistencies in the case law.

Of these different standards, the middle-of-the-road approaches of the First, Fourth, and Tenth Circuits come closest to striking the appropriate balance between requiring an employer to prove too much and not enough. The Eighth and Ninth Circuits" "actual imposition" test requires too much, particularly in the context of employee morale, because it is nearly impossible to prove an accommodation will harm employee morale unless an employer actually implements the accommodation and waits to incur harm. This could

${ }^{284}$ See Brown v. Polk Cnty., 61 F.3d 650, 655 (8th Cir. 1995) (undue hardship requires more than proof of mere "grumbling," an employer must show actual imposition on coworkers or disruption of the work routine); EEOC v. Abercrombie \& Fitch Stores, Inc., 966 F. Supp. 2d 949, 962 (N.D. Cal. 2013) (noting "[t]he Ninth Circuit is skeptical of 'hypothetical hardships' based on assumptions about accommodations" never implemented and instead "requires proof of actual imposition or disruption"). Several district courts outside the Eighth and Ninth Circuits have cited with approval the "actual imposition" standard. See, e.g., Hickey v. State Univ. N.Y. Stony Brook Hosp., No. 10-CV1282(JS)(AKT), 2012 WL 3064170, at *9 n.10 (E.D.N.Y. July 27, 2012); EEOC v. Aldi, Inc., No. 06-01210, 2009 WL 3183077, at *15 (W.D. Pa. Sept. 30, 2009); Hellinger v. Eckerd Corp., 67 F. Supp. 2d 1359, 1365 (S.D. Fla. 1999); Banks v. Serv. America Corp., 952 F. Supp. 703, 709-10 (D. Kan. 1996).

285 See Weber, 199 F.3d at 274; see also Virts v. Consol. Freightways Corp. of Del., 285 F.3d 508, 520-21 (6th Cir. 2002) (approving of Weber's "mere possibility" standard). Additionally, a number of district courts outside the Fifth and Sixth Circuits have cited with approval the "mere possibility" standard. See, e.g., Sanchez-Rodriguez v. AT\&T Wireless, 728 F. Supp. 2d 31, 43 (D.P.R. 2010); Howard v. Life Care Ctrs., No. 5:06-cv276-Oc-10GRJ, 2007 WL 5023585, at *7 n.14 (M.D. Fla. Oct. 26, 2007); Perkins v. Town of Princeville, No. 4:04-CV-168-H(2), 2006 WL 4694727, at*4 (E.D.N.C. Apr. 19, 2006).

${ }^{286}$ Cloutier v. Costco Wholesale Corp., 390 F.3d 126, 135 (1st Cir. 2004) (internal quotation marks omitted); see also Toledo v. Nobel-Sysco, Inc., 892 F.2d 1481, 1490 (10th Cir. 1989).

287 See EEOC v. Firestone Fibers \& Textiles Co., 515 F.3d 307, 317 (4th Cir. 2008) (accommodation not required if employer "reasonably believes that an accommodation would entail a violation of the applicable CBA or impose more than a de minimis impact on coworkers") (citation omitted) (internal quotation marks omitted). 
exacerbate the hardship to an employer if, for example, employees were to quit their jobs because of how an accommodation impacts them. The Fourth Circuit pointed out the unfairness of this approach, reasoning in Firestone that "an employer is not required to wait until it feels the effects of the proposed accommodation before determining its reasonableness," and that "employers must be given leeway to plan their business operations and possible accommodative options in advance, relying on an accommodation's predictable consequences along the way." 288 By contrast, the Fifth and Sixth Circuits' "mere possibility" standard requires too little of employers. On its face, this test allows an employer to establish undue hardship simply by articulating a harm to coworkers within any realm of possibility. ${ }^{289}$ This seems at odds with Title VII's intent. Although the de minimis standard is undeniably low, it nonetheless imposes an obligation on employers to prove at least some degree of harm. The "mere possibility" test falls short of this standard because it enables an employer to circumvent its religious accommodation obligations based on conjecture or hypothetical hardships.

The First, Fourth, and Tenth Circuits take into consideration the reasonable likelihood that an accommodation will result in hardship. The First and Tenth Circuits ask what specific hardships are likely to result from a specific accommodation proposal, whereas the Fourth Circuit examines whether an employer reasonably believes an accommodation will result in hardship. These approaches can be combined into a "reasonable likelihood" standard, whereby courts and employers alike can assess the validity of a morale-based hardship by asking whether it is reasonably likely that an accommodation will cause more than de minimis harm to coworker morale. For example, the Firestone court determined it was reasonably likely that granting one employee substantially more leave time than his coworkers would hurt morale because "[o]ther employees may be left wondering why they are forced to work during valuable personal or family time despite having higher seniority." 290 The court did not require proof of actual harm or coworker complaints to reach this conclusion, but it also did not allow the mere possibility of harm to carry the day. Instead, it focused on the reasonable likelihood of harm to employee morale.

288 Id. (citation omitted) (internal quotation marks omitted).

${ }^{289}$ In fairness, cases applying the "mere possibility" standard generally involve possibilities of coworker harm that seem plausible. See, e.g., Bruff v. N. Miss. Health Servs., Inc., 244 F.3d 495, 501 (5th Cir. 2001) (exempting counselor from having to discuss homosexuality with clients could have required other counselors to assume a disproportionate workload, either by taking on additional clients or by traveling with the plaintiff to sessions to be available in case a problematic subject area came up); Weber, 199 F.3d at 274 (allowing a truck driver to avoid overnight runs with coworkers of the opposite sex potentially could have caused other drivers to earn less money or receive less rest and time off between shifts).

${ }^{290}$ Firestone Fibers \& Textiles Co., 515 F.3d at 318. 
Focusing on the reasonable likelihood an accommodation would harm coworker moral resolves many of the criticisms of the "actual imposition" and "mere possibility" standards. An employer would not have to implement an accommodation to prove it would harm employee morale, nor could the employer meet its burden simply by articulating a hypothetical harm. The middle ground represents the most viable option, as the reasonable-likelihood standard is high enough that employers must carefully consider the potential effects of an accommodation, yet low enough that employers can deny religious accommodations in appropriate cases without having to fear excessive judicial scrutiny.

\section{Potential Impact}

Employee morale warrants the same legal protection as any other business asset that could be harmed by a religious accommodation. In fact, a case can be made for affording morale even greater protection in light of its farreaching influence on performance. Despite the importance of morale, courts are often unsure how coworkers' feelings should factor into whether an employee is entitled to an accommodation. The recommendations outlined in this Article bring clarity to this issue by encouraging both courts and employers to change the way they think about employee morale. The potential impact of these recommendations is threefold. First, it would be easier for an employer to establish undue hardship when an accommodation hurts morale by negatively impacting coworkers' employment, but harder for an employer to establish undue hardship if the harm to morale stems from coworkers' animus or misunderstanding of the law. Second, innocent coworkers would have greater voice in whether an employer provides a religious accommodation, but only when an accommodation threatens to negatively impact their own employment. Third, these recommendations could bring continuity and consistency to the case law that would guide, rather than confuse, legal practitioners and employers in navigating this complex and sensitive issue.

On balance, these recommendations would make it easier for an employer to prove morale-based undue hardship, but only in appropriate cases. Although the Supreme Court has made clear that any cost to an employer that is more than de minimis constitutes an undue burden, ${ }^{291}$ employers face an uphill battle in proving morale-based hardship. This may be due, in part, to fear among the courts that coworkers could wield improper influence over accommodation decisions. Requiring courts to distinguish between valid and invalid harm to morale largely alleviates this concern by ensuring courts only take into consideration harm to morale based on an accommodation's impact on others' employment while disregarding harm based on religious animus or ignorance of the law. The other major impediment to establishing a morale-

${ }^{291}$ See Trans World Airlines, Inc. v. Hardison, 432 U.S. 63, 84 (1977). 
based hardship is that harm to morale is less tangible than other types of business outcomes and consequently can be more difficult to prove. This barrier can be diminished by allowing an employer to establish undue hardship based on the reasonable likelihood that an accommodation would cause more than de minimis harm to coworker morale (without having to further prove how harm to employee morale will adversely impact the business). By affording morale greater protection, courts could send a strong message that morale matters as much as other business assets. Employers could then invest in morale initiatives with the confidence that courts will not undermine their efforts simply because an employee seeks a religious accommodation.

These recommendations would also give greater voice to innocent coworkers in appropriate cases in influencing whether an employer provides a religious accommodation. Distinguishing between valid and invalid harm to morale would empower coworkers when an accommodation could adversely impact the terms or conditions of their own employment, but silence them when their disgruntlement stems from religious animus or perceptions of unfairness based on ignorance of the law. While it is true employees are not immune from having to endure some level of discomfort or annoyance from coworkers, ${ }^{292}$ employment discrimination law generally draws the line at behavior that affects the terms and conditions of one's employment. ${ }^{293}$ In the religious accommodation context, the threshold for harm is substantially lower, as an employer is only required to prove more than de minimis cost. ${ }^{294}$ More forceful protection of employee morale sends a strong message that employees need not suffer in silence when a religious accommodation threatens to make their jobs less enjoyable. Allowing coworkers to voice their concerns about an accommodation would let them feel like their opinions matter, which may itself bolster morale. ${ }^{295}$ It could also provide employers with an opportunity to educate and, if necessary, correct their employees regarding religious accommodation rights under Title VII.

${ }^{292}$ See Peterson v. Hewlett-Packard Co., 358 F.3d 599, 607 (9th Cir. 2004) (an accommodation does not create undue hardship merely because coworkers find the conduct irritating or unwelcome, as "[c]omplete harmony in the workplace is not an objective of Title VII").

293 See, e.g., Meritor Sav. Bank, FSB v. Vinson, 477 U.S. 57, 67 (1986) (harassment is unlawful if the conduct is "sufficiently severe or pervasive "to alter the conditions of [the victim's] employment"'); Bennington v. Caterpillar, Inc., 275 F.3d 654, 660 (7th Cir. 2001) (to establish constructive discharge a plaintiff must prove she was subjected to working conditions "so intolerable that a reasonable person would have been compelled to resign”); see also U.S. EQUAL EMP. OPPORTUNITY COMM'N, COMPLIANCE MANUAL, supra note $115, \S 12-\mathrm{IV}-\mathrm{C}-6$-a (religious expression can create undue hardship if disruptive to the work of other employees).

294 Hardison, 432 U.S. at 84.

295 See BOWLES \& COOPER, supra note 23, at 61-62 (the process of measuring morale and feeding back the results can boost morale by giving a voice to the lowest-level employee). 
Perhaps the most significant benefit of these recommendations is the potential to bring consistency and continuity to an area of the law where courts often find themselves at odds with one another. When one court determines an employer does not have to accommodate an employee's request not to work weekends because it could hurt morale, ${ }^{296}$ but another court reaches the opposite conclusion ${ }^{297}$ - or when one court allows an employer to fire an employee for posting Bible passages, ${ }^{298}$ but another court upholds a supervisor's right to quote scriptures and hold prayer meetings ${ }^{299}$ - it is little wonder that employers and employees, judges and lawyers, often are unsure how coworker morale factors into the availability of a religious accommodation. By no means do these recommendations eliminate the need for courts to evaluate the merits of religious accommodation claims on a caseby-case basis. ${ }^{300}$ But they would help ensure cases are analyzed in a consistent manner regardless of factual differences. Such consistency in the case law is essential if we are to ever approach Title VII's aim of eradicating religious discrimination in the workplace.

\section{CONCLUSION}

Tension between religious accommodations and employee morale is unlikely to go away anytime soon. As religion becomes increasingly prominent in the workplace, ${ }^{301}$ both the frequency and variety of requests for religious accommodations will likely increase. At the same time, employers are placing unprecedented emphasis on employee morale in light of study after study linking morale to performance. Employers face a difficult dilemma when an accommodation threatens coworker morale. Either the employer can provide the accommodation and risk alienating other employees, or it can deny the accommodation and brace itself for the seemingly inevitable lawsuit. In theory, an employer should be able to resolve this predicament simply by

\footnotetext{
${ }^{296}$ See generally EEOC v. Firestone Fibers \& Textiles Co., 515 F.3d 307 (4th Cir. 2008).

297 See generally Opuku-Boateng v. California, 95 F.3d 1461 (9th Cir. 1996).

298 See generally Peterson v. Hewlett-Packard Co., 358 F.3d 599 (9th Cir. 2004).

299 See generally Brown v. Polk Cnty., 61 F.3d 650 (8th Cir. 1995).

300 See Crider v. Univ. Tenn., Knoxville, 492 F. App'x 609, 612 (6th Cir. 2012) ("[W]hether an accommodation is reasonable is determined on a case-by-case basis."); Sturgill v. United Parcel Serv., Inc., 512 F.3d 1024, 1030 (8th Cir. 2008) ("What is reasonable depends on the totality of the circumstances and therefore might, or might not, require elimination of a particular, fact-specific conflict."); Tooley v. Martin-Marietta Corp., 648 F.2d 1239, 1243 (9th Cir. 1981) (determination of undue hardship "must be made by considering 'the particular factual context of each case."').

301 See James L. Nolan, Doing the Right Thing at Work: A CATHOlic’s Guide to FAith, Business, AND ETHICS 20 (2006); Eileen P. Kelly, Accommodating Religious Expression in the Workplace, 20 EMP. RESPONSIBILITIES \& RTS. J. 45, 46 (2008); Mark A. Spognardi \& Staci L. Ketay, In the Lion's Den: Religious Accommodation and Harassment in the Workplace, 25 EMP. REL. L.J. 7, 7-8 (2000).
} 
asking whether the accommodation would result in more than de minimis harm. But in reality, what should be a relatively straightforward analysis has become obfuscated by a legal system that is unsure how coworker morale factors into an employer's accommodation obligation. To the floundering employer, the case law acts more as an anchor than as a life vest.

The biblical mandate to bear one another's burdens ${ }^{302}$ applies with some force in the context of religious accommodation law. The Supreme Court's observation that sharing the burden of past discrimination is "presumptively necessary" 303 holds true for religious accommodations that impact other workers. Because most religious accommodations impose on coworkers in some way or another, it is essential other employees shoulder some of the burden of an accommodation - even if inconvenient, annoying, or seemingly unfair. However, when an accommodation causes more than de minimis harm to coworker morale, it is an employer's right — and a court's obligation - to protect this crucial business asset. The recommendations offered in this Article bring clarity and consistency to an area of the law that is often complex and confusing. Balancing the rights of an accommodation seeker and the rights of coworkers within the appropriate framework will protect employees in exercising their religious beliefs while ensuring coworkers are not saddled with a heavier burden than the law requires them to bear.

302 See Galatians 6:2 ("Bear one another's burdens, and so fulfill the law of Christ.").

${ }^{303}$ See Franks v. Bowman Transp. Co., Inc., 424 U.S. 747, 777 (1976). 